\title{
Endoplasmic reticulum stress and the unfolded protein response in pancreatic islet inflammation
}

\author{
Kira Meyerovich1,*, Fernanda Ortis ${ }^{2, *}$, Florent Allagnat ${ }^{3}$ and Alessandra K Cardozo ${ }^{1}$ \\ 'ULB Center for Diabetes Research, Université Libre de Bruxelles (ULB), Brussels, Belgium \\ 2Department of Cell and Developmental Biology, Universidade de São Paulo, São Paulo, Brazil \\ 3Department of Vascular Surgery, Centre Hospitalier Universitaire Vaudois (CHUV), Lausanne, \\ Switzerland \\ ${ }^{*}(\mathrm{~K}$ Meyerovich and F Ortis contributed equally to this work)
}

Correspondence should be addressed to A K Cardozo Email akupperc@ulb.ac.be

\begin{abstract}
Insulin-secreting pancreatic $\beta$-cells are extremely dependent on their endoplasmic reticulum (ER) to cope with the oscillatory requirement of secreted insulin to maintain normoglycemia. Insulin translation and folding rely greatly on the unfolded protein response (UPR), an array of three main signaling pathways designed to maintain ER homeostasis and limit ER stress. However, prolonged or excessive UPR activation triggers alternative molecular pathways that can lead to $\beta$-cell dysfunction and apoptosis. An increasing number of studies suggest a role of these pro-apoptotic UPR pathways in the downfall of $\beta$-cells observed in diabetic patients. Particularly, the past few years highlighted a cross talk between the UPR and inflammation in the context of both type 1 (T1D) and type 2 diabetes (T2D). In this article, we describe the recent advances in research regarding the interplay between ER stress, the UPR, and inflammation in the context of $\beta$-cell apoptosis leading to diabetes.
\end{abstract}

Key Words
- pancreatic beta cells
- inflammation
- unfolded protein
response
- NF-kB
- diabetes

\section{Introduction}

The endoplasmic reticulum (ER) is an intracellular organelle responsible for several crucial features of cellular homeostasis, such as protein maturation and transport and $\mathrm{Ca}^{2+}$ homeostasis (Ellgaard \& Helenius 2003, Walter $\&$ Ron 2011). Therefore, maintaining the ER homeostasis is crucial for proper cellular function and cells have developed an adaptive response to the disruption of this homeostasis named the unfolded protein response (UPR). The UPR encompasses an array of signaling pathways mediated by the action of three signaling proteins named inositol-requiring protein $1 \alpha$ (IRE1 $\alpha$ ), protein kinase RNA (PKR)-like ER kinase (PERK), and activating transcription factor 6 (ATF6) (Walter \& Ron 2011).
Upon ER stress, IRE1 $\alpha$ autophosphorylates leading to alternate splicing and translation of the active form of the transcription factor XBP1 (XBP1s), which stimulates the expression of chaperones and components of the ER-associated protein degradation (ERAD) pathway (Pincus et al. 2010, Walter \& Ron 2011). Moreover, IRE1 $\alpha$ selectively degrades mRNAs (RIDD, regulated IRE1-dependent decay), thereby decreasing the ER protein load (Maurel et al. 2014). PERK also undergoes autophosphorylation and activation upon ER stress, leading to phosphorylation of the eukaryotic initiation factor $2 \alpha$ (eIF2 $\alpha$ ) and decreased general translational activity, reducing ER protein overload (Walter \& Ron 2011). However, PERK-mediated eIF2 $\alpha$

Published by Bioscientifica Ltd 
phosphorylation also triggers selective induction of ATF4 (Lu et al. 2004). Moreover, PERK directly phosphorylates and activates the nuclear erythroid 2 p45-related factor 2 (NRF2) by disrupting the NRF2-KEAP1 (Kelch-like ECH-associated protein 1) complex (Cullinan \& Diehl 2006). Both NRF2 and ATF4 induce the expression of antioxidant genes, which counteracts the increase in reactive oxygen species (ROS) due to the boosted oxidation/reduction reactions during UPRstimulated protein folding (Harding et al. 2003, Malhotra \& Kaufman 2007, Hybertson et al. 2011). However, PERK/ ATF4 can initiate pro-apoptotic responses via upregulation of the C/EBP homologous protein (CHOP) (McCullough et al. 2001, Oyadomari et al. 2002a,b, Oyadomari \& Mori 2004). Activation of the third UPR branch, the transcription factor ATF6, is mediated via cleavage by site- 1 and site- 2 proteases (SP1 and SP2) in the Golgi. Cleaved ATF6 regulates the expression of several genes encoding chaperones, ERAD components, and XBP1 (Hetz 2012). Notably, the three UPR branches may be independently and differentially activated depending on the type and duration of ER stress and the cell type (Cardozo et al. 2005, Gomez et al. 2008, Engin et al . 2013). However, it remains unclear how this differential activation is coordinated.

The UPR can be divided into two distinct phases: the initial or the adaptive phase and the second or the maladaptive phase. While the first phase is characterized by cell survival and restoration of ER homeostasis by the mechanisms described above, the second phase is initiated under conditions of irreversible ER stress and results in the activation of pro-inflammatory responses and cell death (for more details of cell death pathways activated during ER stress, please see reviews of Tabas \& Ron 2011, Gorman et al. 2012, Cao \& Kaufman 2014).

Glucose homeostasis depends on a tightly regulated secretion of insulin by the pancreatic $\beta$-cells. The everchanging demand for insulin production and secretion in response to nutrient stimulation relies greatly on the $\mathrm{ER}$, to ensure synthesis and proper folding of pro-insulin (Back et al. 2009, Hassler et al. 2015). As a result, $\beta$-cells are exquisitely sensitive to additional ER pressure and accumulating evidence indicate a major role of the UPR in the context of $\beta$-cell demise leading to diabetes (Brozzi \& Eizirik 2016, Hasnain et al. 2016).

This article focuses on (1) the signal transduction pathways involved in the UPR and their connections to inflammation, (2) the specific role of the UPR in pancreatic $\beta$-cell survival in the context of diabetes, (3) the interplay between UPR signaling and inflammation in pancreatic $\beta$-cells, and (4) the potential ER stress-targeting therapies to treat diabetes.

\section{UPR and inflammation}

The pro-inflammatory signaling pathways initiated downstream of the UPR are mainly coordinated via activation of the nuclear factor $\mathrm{\kappa B}$ (NF- $\mathrm{\kappa B}$ ) and activating protein (AP)-1 transcription factors (Hotamisligil 2010, Garg et al. 2012). NF-kB is a major modulator of inflammatory responses controlled by the IкB kinase (IKK) complex formed by IKK $\beta$, IKK $\alpha$, and IKK $\gamma$ (Shih et al. 2011). When stimulated, the IKK complex leads to phosphorylation and degradation of the inhibitory $\mathrm{\kappa B}$ (IкB) protein, allowing NF-кB dimers to migrate to the nucleus and induce the expression of several cytokines and chemokines (Shih et al. 2011). During ER stress, NF-кB can be induced due to PERK-mediated attenuation of protein translation, leading to decreased levels of IкB proteins and consequent increase of NF- $\mathrm{kB}$ (Fig. 1) (Deng et al. 2004). IRE1 $\alpha$ may also trigger NF- $\mathrm{KB}$ activation by binding to the tumor necrosis factor (TNF)-receptor associated factor 2 (TRAF2), which activates the IKK complex (Kaneko et al. 2003, Hu et al. 2006) (Fig. 1). Loss of either IRE1 $\alpha$ or PERK reduces NF- $\mathrm{kB}$ during ER stress, indicating a synergistic effect of these kinases on NF-kB activity (Tam et al. 2012). In addition, two studies have shown that ATF6 stimulates NF- $\mathrm{kB}$ activity downstream of AKT phosphorylation (Yamazaki et al. 2009, Rao et al. 2014).

AP1 is a dimer composed of transcription factors from different families of proteins such as JUN, FOS, ATF, and MAF (Davis 2000). The diversity of AP1 dimers implicates this transcription factor in different cellular responses. Thus, AP1 modulates inflammation by upregulating the expression of cytokines, chemokines, and other pro-inflammatory molecules (Angel et al. 2001, Shaulian \& Karin 2001, Eferl \& Wagner 2003). Several proinflammatory genes have binding sites for both AP1 and NF-кB (Angel et al. 2001). During ER stress, AP1 activation can be initiated downstream of IRE1 $\alpha$, via TRAF2mediated JNK phosphorylation (Fig. 1) (Urano et al. 2000). Moreover, both NF-кB and AP1 signaling may be activated by ROS generated during ER stress (Garg et al. 2012).

Besides NF- $\mathrm{kB}$ and AP1, the UPR may trigger proinflammatory responses via XBP1s and ATF4, since these transcription factors were shown to stimulate the expression of pro-inflammatory cytokines and chemokines, such as TNF, IL6, IL8, C-X-C motif ligand 2 (CXCL2), and C-X-C motif ligand 3 (CXCL3) in endothelial cells during UPR (Gargalovic et al. 2006). ATF4 was also shown to contribute to LPS-induced $\mathrm{C}-\mathrm{C}$ motif ligand 2 (CCL2) production in endothelial cells and retina and IL6 in macrophages (Iwasaki et al. 2014, Huang et al. 2015).

Published by Bioscientifica Ltd. 


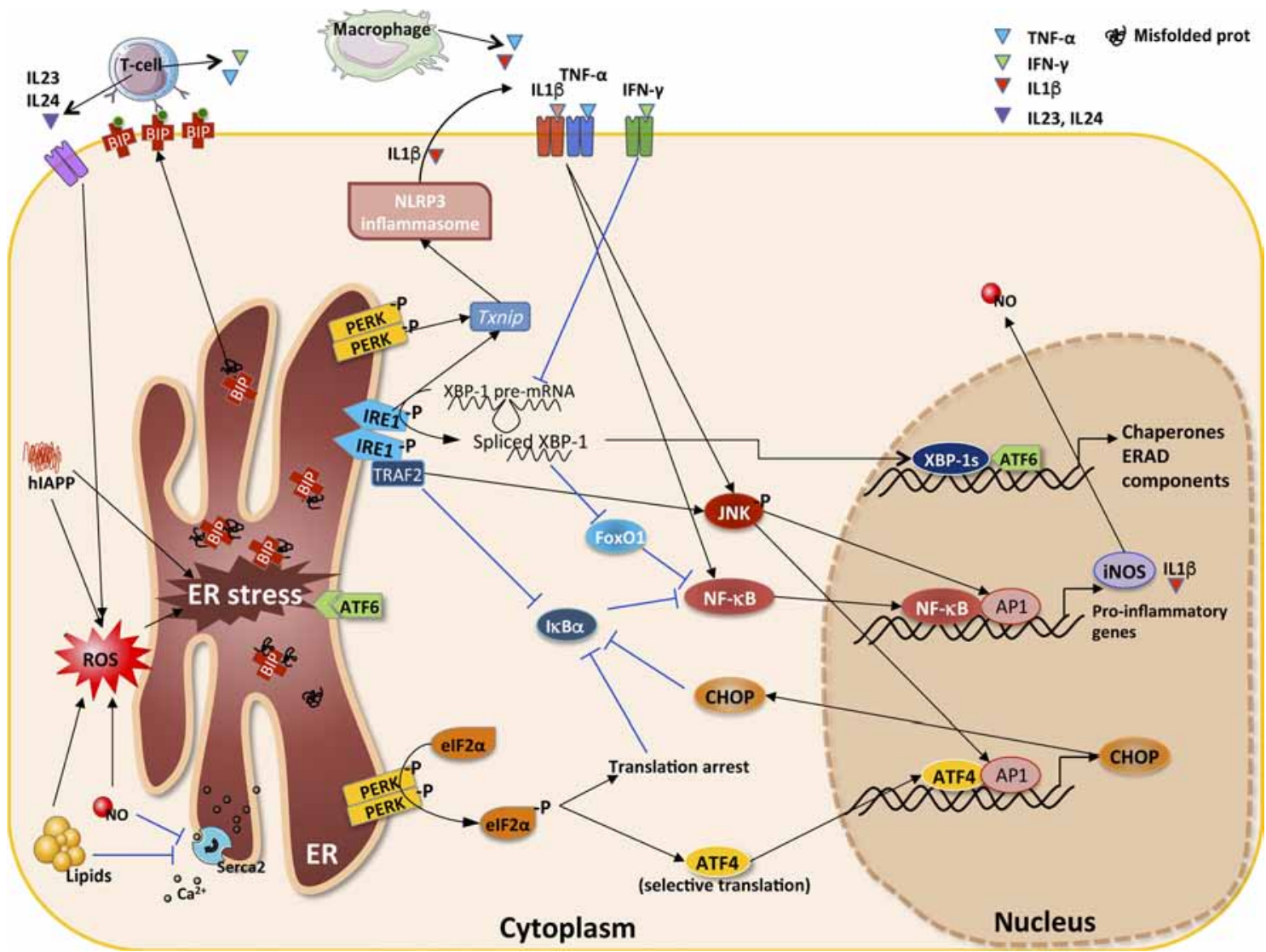

Figure 1

Schematic representation of the possible cross talks between UPR and pro-inflammatory pathways in pancreatic $\beta$-cells under ER stress. Pro-inflammatory cytokines (IL1 $\beta$, TNF, IFN, IL23, and IL24), lipids (free fatty acids), IAPP aggregates, and Serca2 blockers induce ER stress by diverse mechanisms such as NO formation, ROS production, and ER calcium depletion leading to UPR activation in pancreatic $\beta$-cells. UPR-mediated activation of IRE $1 \alpha$ (by its dimerization and phosphorylation) may lead to the recruitment of the adaptor protein tumor necrosis factor receptor-associated factor 2 (TRAF2) leading to activation of NF-KB (via IKB $\alpha$ degradation) and JNK. JNK activation in turn increases AP1 activity and both AP1 and NF- $\mathrm{kB}$ migrate to the nucleus to induce expression of pro-inflammatory genes. Under pro-inflammatory stimulation, JNK (via AP1) upregulates CHOP expression, consequently increasing I $\mathrm{KB} \alpha$ degradation, NF- $\mathrm{KB}$ activation and elevated NO production further potentiating ER stress responses. Furthermore, IRE1 $\alpha$ induces the alternative splicing of XBP1s, which may increase NF-kB activation via its inhibitory effect on FOX01. Finally, IRE1 $\alpha$ increases degradation of miRNA that targets Txnip, leading to increased activation of the NLRP3 inflammasome and IL1 $\beta$ production, under certain conditions. Activation of the PERK arm in ER-stressed $\beta$-cells might activate NF-KB via ATF4-mediated increase in the expression of CHOP. Moreover, PERK inhibits general protein translation (via phosphorylation and activation of elF2 $\alpha$ ), which may also increase NF-kB activation, due to inhibition of de novo IkB $\alpha$ expression. Finally, PERK was also shown to contribute to the activation of the NLRP3 inflammasome and IL1 $\beta$ release. Furthermore, cytokine-induced ER stress stimulates translocation of citrullinated BiP to the plasma membrane where it may activate the immune system, thereby contributing to the inflammatory response in the islets. This ER stress-mediated inflammatory state contributes to the maintenance of ER stress and probably leads to $\beta$-cell demise. Additional information and supporting references are provided in the text.

Furthermore, XBP1s is implicated in synergistic production of type 1 interferons (IFNs), for example, IFN- $\beta$ or IFN$\alpha$, in response to combination of ER stress and Toll-like receptor (TLR) signaling in macrophages (Martinon et al. 2010, Zeng et al. 2010).

Both the UPR and inflammation are important protective cellular/tissue responses that when deregulated can lead to cellular damage. In line with this, UPR dysfunction is involved in many autoimmune and inflammatory disorders, such as diabetes (Hotamisligil
2010, Kaser \& Blumberg 2010, Oslowski \& Urano 2011a, Chaudhari et al. 2014).

\section{Pancreatic $\beta$-cell susceptibility to ER stress}

The two main forms of diabetes are T1D and T2D. T1D is primarily caused by an autoimmune attack leading to $\beta$-cell destruction and insulin deficiency (Seino et al. 2010). T2D is triggered by the combination of insulin resistance and impaired $\beta$-cell function and survival, mostly secondary

Published by Bioscientifica Ltd. 
to metabolic factors through a process referred to as glucolipotoxicity (Seino et al. 2010). Both pathologies are characterized by decreased $\beta$-cell mass secondary to apoptosis; however, $\beta$-cell loss is more marked in T1D and is a relative late event in $\mathrm{T} 2 \mathrm{D}$, probably contributing to secondary failure of oral therapies (Christoffersson et al. 2016, Hara et al. 2016). In T1D, pro-inflammatory cytokines are early mediators of $\beta$-cell apoptosis, while in T2D a combination of high glucose, cholesterol, and free fatty acid (FFA) levels contribute to $\beta$-cell death. Cytokines, high glucose, and FFAs induce ER stress in $\beta$-cells (Eizirik et al. 2008, Cnop et al. 2010, Brozzi \& Eizirik 2016). CHOP and BiP levels are increased in islets from individuals with T1D as compared with nondiabetic individuals (Marhfour et al. 2012). In islets from T2D patients, an increased ER density together with augmented levels of CHOP and the ER chaperones BiP and DNAJC3 (also known as p58IPK) was observed as compared with nondiabetic controls (Huang et al. 2007, Laybutt et al. 2007, Marchetti et al. 2007). These studies suggest an involvement of the ER stress pathways in the development of both T1D and T2D.

$\beta$-cells are unique due to their capacity to sense blood glucose and to respond to changeable demands in insulin secretion. An increase in insulin production, up to 20 -fold induced by glucose, is a common physiological response of $\beta$-cells that results in an intense trafficking of proteins through the ER (Eizirik et al. 2008). Therefore, $\beta$-cells express high levels of the UPR transducers IRE1 $\alpha$ and PERK, which are necessary for strict quality control of pro-insulin synthesis and to limit oxidative stress induced during the insulin folding, a process that could lead to $\beta$-cell failure (Lipson et al. 2006, Eizirik et al. 2008, Back et al. 2009, Oslowski \& Urano 2011a, Hassler et al. 2015). Thus, $\beta$-cell exposure to intermittent physiological levels of high glucose increases pro-insulin production with a controlled and regulated UPR activation, which contributes to proper $\beta$-cell function and survival (Oslowski \& Urano 2011a). However, chronic exposure to hyperglycemia induces prolonged activation of the IRE1 $\alpha$ pathway leading to $\beta$-cell apoptosis (Lipson et al. 2006, 2008, Elouil et al. 2007, Pirot et al. 2007a, Hou et al. 2008, Han et al. 2009, Jonas et al. 2009). Sustained activation of ATF6 also contributes to $\beta$-cell dysfunction via inhibition of the insulin promoter activity and induction of $\beta$-cell death (Seo et al. 2008). Similarly, persistent XBP1s production hampers $\beta$-cell function, eventually leading to apoptosis (Allagnat et al. 2010). Sustained PERK activation/eIF $2 \alpha$ phosphorylation contributes to $\beta$-cell apoptosis via inhibition of protein translation leading to decreased levels of the anti-apoptotic protein MCL1 and by inducing the pro-apoptotic protein CHOP (Oyadomari et al. 2002b, Scheuner et al. 2005, Cnop et al. 2007, Song et al. 2008, Allagnat et al. 2011, 2012).

Several studies in animal models demonstrated a prominent role for the different UPR pathways on $\beta$-cell survival and function (Eizirik et al. 2008, Volchuk \& Ron 2010). Moreover, mutations in diverse genes leading to $\beta$-cell ER stress contribute to the development of diabetes in humans (Inoue et al. 1998, Delepine et al. 2000, Stoy et al. 2007, Colombo et al. 2008, Polak et al. 2008, Liu et al. 2015, Sun et al. 2015). These results suggest that tight control of ER homeostasis is crucial to maintain $\beta$-cell function and survival.

\section{Inflammation induces ER stress in pancreatic $\beta$-cells}

\section{Type 1 diabetes}

The most evident role of inflammation-induced ER stress in pancreatic $\beta$-cells is in the context of T1D (Brozzi \& Eizirik 2016). At early stages of the disease, T-cells, macrophages, dendritic cells, and natural killer cells surround the islets in a process called insulitis (Eizirik et al. 2009). During insulitis, $\beta$-cells are exposed to pro-inflammatory cytokines and free radicals, such as interleukin-1 $\beta$ (IL1 $\beta$ ), TNF, IFN- $\gamma$, interleukin-17 (IL17), and NO secreted by these infiltrating immune cells, inducing a first wave of $\beta$-cell apoptosis (Eizirik et al. 2009). Cytokine-mediated $\beta$-cell death is a complex phenomenon involving NO production, activation of the diverse transcription factors (e.g., NF-кB and STAT1), MAP kinases (e.g., JNK), and ER stress that culminate in the induction of the intrinsic proapoptotic pathway (Eizirik et al. 2009, Gurzov \& Eizirik 2011). In addition, pro-inflammatory cytokines stimulate the expression and secretion of cytokines and chemokines by the $\beta$-cells themselves, initiating a pro-inflammatory dialog between $\beta$-cells and the immune system (Eizirik et al. 2009, Grieco et al. 2011). This contributes to massive T-cell infiltration within the islets and final $\beta$-cell destruction (Eizirik et al. 2009, Grieco et al. 2011). Recent evidences suggest that ER stress is also involved in the pro-inflammatory responses induced by cytokines in $\beta$-cells (see below, ER stress-induced inflammation in pancreatic $\beta$-cells).

Increased expression of ER stress markers is observed in insulitis-positive and cell-containing islets of T1D patients (Marhfour et al. 2012). In line with these results, virus-inducible autoimmune diabetes in the diabetes-resistant BB (BBDR) rat is accompanied by an

Published by Bioscientifica Ltd. 
activation of the IRE1 $\alpha / \mathrm{XBP} 1$ pathway preceding insulitis and a later increase in CHOP expression and caspase 3 activation coinciding with diabetes development (Yang et al. 2013). Moreover, expression of ER stress markers and $\beta$-cell dysfunction appear before the development of hyperglycemia in nonobese diabetic (NOD) mice, in which a clear increase in the expression of NF- $\mathrm{kB}$ target genes is observed (Tersey et al. 2012). These results indicate, in vivo, a cross talk between inflammatory signaling and ER stress induction that probably contributes to diabetes onset.

Exposure of rat primary $\beta$-cells to IL $1 \beta+\mathrm{IFN}-\gamma$ in vitro decreases the expression of Serca2b, the main $\mathrm{Ca}^{2+}$ pump driving $\mathrm{Ca}^{2+}$ influx into the ER, leading to ER $\mathrm{Ca}^{2+}$ depletion and activation of the UPR in rat pancreatic $\beta$-cells (Cardozo et al. 2005). Cytokineinduced ER stress in rat primary $\beta$-cells is a consequence of NF-кB-mediated NO production, since inhibition of NO prevents Serca2b downregulation, splicing of XBP1 and CHOP upregulation (Fig. 1) (Cardozo et al. $2005)$. By contrast, in mouse $\beta$-cells/islets, cytokinemediated Serca2b downregulation and UPR activation are independent of NO production (Chan et al. 2011). However, in these $\beta$-cells, the free radical contributes to the activation of pro-apoptotic responses by upregulating CHOP and decreasing the expression of ER chaperones (Chan et al. 2011). In human $\beta$-cells, pro-inflammatory cytokines also induce ER stress responses (Allagnat et al. 2012, Brozzi et al. 2015) and, similar to mouse $\beta$-cells, this effect is independent of NO production (Brozzi et al. 2015). The factors inducing ER stress in cytokine-treated human $\beta$-cells remain to be determined.

Cytokine-induced UPR in $\beta$-cells is characterized by a strong activation of the PERK-ATF4-CHOP pathway and a defective induction of ER chaperones, probably due to the lack of ATF6 activation and a modest increase in XBP1 splicing (Rasschaert et al. 2003, Cardozo et al. 2005, Ortis et al. 2010). Moreover, IFN- $\gamma$ potentiates IL1 $\beta$-induced death of a rat insulinoma cell line (INS-1E cells) by decreasing the expression of spliced Xbp1 mRNA and several ER chaperones (Fig. 1) (Pirot et al. 2006). Cytokine-mediated NO production was shown to inhibit the expression of the ER chaperones, foldases, and degradation enhancers, decreasing the capacity of a mouse insulinoma cell line (MIN6) cells and primary mouse $\beta$-cells to alleviate ER stress (Chan et al. 2011). In line with these in vitro results, the levels of XBP1s and ATF6 are diminished in islets from T1D patients and two mouse models of T1D (NOD and RIP-LCMV-GP (rat insulin promoter-lymphocytic choriomeningitis virus-glycoprotein)) (Engin et al. 2013).
Interestingly, administration of the chemical chaperone TUDCA increases ATF6 expression and decreases $\beta$-cell death, islet inflammation, and development of diabetes in these mouse models (Engin et al. 2013). These results indicate that a defective expression of ER chaperones may contribute to $\beta$-cell susceptibility to ER stress and cell death in T1D.

\section{Type 2 diabetes}

Obesity, a major risk factor for T2D, is characterized by systemic low-grade chronic inflammation in the form of increased circulating levels of pro-inflammatory cytokines such as TNF, IL1 $\beta$, and IL6 and lower levels of anti-inflammatory adipokines such as adiponectin and omentin (Pereira \& Alvarez-Leite 2014). In line with this, elevated circulating levels of pro-inflammatory cytokines characterize the early (or pre-clinical) stages of T2D and exhibit a graded increase with the disease progression (Duncan et al. 2003, Grossmann et al. 2015). Interestingly, recent studies also suggest links between inflammation and ER stress in T2D patients at the level of the immune system. Thus, peripheral blood mononuclear cells (PBMCs) of T2D patients express higher levels of BiP, CHOP, and thioredoxin-interacting protein (TXNIP), and lower levels of IкB $\alpha$ and NRF2 (Lenin et al. 2015, Mozzini et al. 2015), suggesting chronic ER stress in PBMCs and increased proinflammatory signals in those patients. Whether these relatively low levels of circulating cytokines affect $\beta$-cell survival in vivo remains unclear, although they seem to affect the secretory function of INS1E cells in vitro (Eizirik 1991, Zhang \& Kim 1995, Kiely et al. 2007). FFAs may also activate TLR2 and TLR4 in mouse islets, leading to the expression of pro-inflammatory factors via NF- $\mathrm{kB}$ (Eguchi et al. 2012, Pal et al. 2012, Yin et al. 2014). This local inflammation probably contributes to increased recruitment of immune cells, particularly macrophages, in the vicinity of islets in T2D patients, promoting a proinflammatory environment and UPR activation (Eguchi \& Manabe 2013, Cucak et al. 2014). Islets from T2D patients produce amyloid polypeptide (hIAPP), which aggregates to form amyloid fibrils. Interestingly, extracellular hIAPP aggregation provokes ER stress and impairs the ubiquitin-proteasome pathway in INS-1 cells (Haataja et al. 2008). Thus, while lipids, via $\mathrm{Ca}^{2+}$ modulation and ROS generation, are probably the major cause of ER stress, $\beta$-cell dysfunction, and apoptosis in T2D (reviewed in (Cnop et al. 2010)), lipid-induced inflammation together with adiposetissue-mediated low-grade inflammation likely contribute to ER stress and to the progression of the disease (Fig. 1).

Published by Bioscientifica Ltd 
Recently, Hasnain et al. (2014) provided a direct evidence for the role of inflammation in ER stress induction in T2D. Thus, they showed that IL23 and IL24 are increased in islets of T2D patients, and that blocking these cytokines partially reduced oxidative and ER stress in the islets and improved glucose tolerance in obese mice (Fig. 1) (Hasnain et al. 2014). The authors further demonstrated that administration of IL22, a cytokine that decreases ROS formation, was able suppress ER stress and improve islet function, leading to the restoration of glucose homeostasis in these animals (Hasnain et al. 2014). Overall, there is a growing amount of evidence suggesting that inflammation contributes to UPR induction and $\beta$-cell fate in both T1D and T2D.

\section{ER stress-induced inflammation in pancreatic $\beta$-cells}

\section{ER stress, NF-кB, and JNK signaling}

Although this research area is not yet well developed, different lines of evidence support a role for the UPR in inducing and/or amplifying inflammatory responses in pancreatic $\beta$-cells. They are mainly focused on the transcription factor NF- $\mathrm{B}$, a key regulator of proinflammatory responses in these cells (Cardozo et al. 2005, Ortis et al. 2010, 2012). Microarray analysis of INS-1E cells exposed to the Serca2 blocker and ER stress inducer cyclopiazonic acid (CPA) demonstrated modulation of pro-inflammatory genes, some of them which are NF-кB dependent (Pirot et al. 2007a). Thus, CPA-treated INS-1E cells express increased levels of the chemokines, CXCL1 and CXCL2; the cytokines IL1 $\beta$, TNF, TNF ligand superfamily member 1 (TNFSF1, previously known as TNF$\beta$ ), and IFN- $\gamma$ receptor; and decreased levels of IL6, IL15, and CCL5 (Pirot et al. 2007a). Later studies showed that CPA and another Serca2 blocker, namely thapsigargin, induce NF- $\kappa$ B activation in INS-1E cells and human islets (Tonnesen et al. 2009, Igoillo-Esteve et al. 2010). Notably, $\mathrm{NF}-\kappa \mathrm{B}$ activation and expression of its downstream genes induced by the Serca2 inhibitors are of a much lower magnitude than that observed in $\beta$-cells treated with pro-inflammatory cytokines (Pirot et al. 2007a, Tonnesen et al. 2009, Igoillo-Esteve et al. 2010). While TNF and IL1 $\beta$ induce a strong NF- $\kappa \mathrm{B}$ activation due to binding to their respective receptors (Shih et al. 2011), the mechanisms linking Serca 2 inhibition with NF- $\mathrm{B}$ activation in $\beta$-cells were not fully investigated. Translational attenuation does not seem to be the main mechanism since salubrinal, a selective inhibitor of eIF2 $\alpha$ dephosphorylation, did not modify CPA-mediated NF- $\mathrm{B}$ activation in human islet cells (Igoillo-Esteve et al. 2010). However, thapsigargin was shown to potentiate cytokine-mediated NF- $\mathrm{B}$ activation and pro-inflammatory gene expression by increasing I $\mathrm{IB} \alpha$ protein degradation in MIN6 cells (Chan et al. 2012). ER calcium depletion is probably an important trigger of NF- $\kappa \mathrm{B}$ activation in $\beta$-cells, since tunicamycin, an agent inducing ER stress via inhibition of protein glycosylation (Oslowski \& Urano 2011b) does not induce or potentiate NF- $\kappa$ B activation in MIN6 and rat primary $\beta$-cells (our own unpublished data) (Chan et al. 2011). A subsequent study by Miani et al. (2012) showed that INS-1E cells or primary rat $\beta$-cells exposed to a low concentration of CPA are sensitized to IL1 $\beta$-mediated pro-inflammatory responses. Thus, expression of NF- $\mathrm{B}$ downstream genes such as FAS, CCL2, CXCL1, and iNOS, as well as NO production were higher in $\beta$-cells pre-exposed to CPA, as compared with cells treated with IL1 $\beta$ alone. This effect was due to a XBP1-mediated degradation of the NF- $\mathrm{kB}$-inhibitor fork head boxO1 (FoxO1) protein (Fig. 1), suggesting pro-inflammatory properties of XBP1 (Miani et al. 2012). However a recent article showed that IRE1 $\alpha / \mathrm{XBP} 1$ ablation in adult mouse islets leads to increased levels of IL1 $\beta$, iNOS, and CXCL2 after exposure to high glucose (Hassler et al. 2015). The authors suggest that this increase in pro-inflammatory gene expression occurs downstream of elevated ROS formation in Ire $1 \alpha^{-/-}$islets and is not a direct effect of XBP1 on these genes (Hassler et al. 2015). Therefore, the outcome of the pro- or anti-inflammatory effects of XBP1 in $\beta$-cells seems to be context dependent and defined by the balance between its anti-apoptotic/ anti-oxidative responses versus its direct pro-inflammatory signaling. This is in agreement with data obtained in other tissues showing that while XBP1 deficiency may stimulate inflammation (Kaser et al. 2008), XBP-1 signaling may also directly induce pro-inflammatory responses (Smith et al. 2008, Martinon et al. 2010, Zeng et al. 2010, Hu et al. 2011, Ziogas et al. 2015).

The transcription factor CHOP is induced upon ER stress downstream of the PERK pathway (Fig. 1) (Oyadomari $\&$ Mori 2004). CHOP contributes to rodent and human $\beta$-cell apoptosis and its expression is upregulated in islets from both T1D and T2D patients (Laybutt et al. 2007, Cunha et al. 2008, Allagnat et al. 2012). Besides its proapoptotic role, recent studies revealed a pro-inflammatory role for CHOP in different disease models, including myocardial inflammation (Miyazaki et al. 2011), lung damage induced by LPS (Endo et al. 2005), chemical hepatocarcinogenesis (DeZwaan-McCabe et al. 2013), and high fat diet-induced diabetes (Maris et al. 2012). Other

Published by Bioscientifica Ltd 
studies have also shown that $\mathrm{CHOP}$ positively regulates the expression of pro-inflammatory cytokines such as IL1 $\beta$ and IL8 and chemokines such as CCL2 in different tissues (Kodama et al. 2005, Endo et al. 2006, Cucinotta et al. 2008, Suyama et al. 2008, Namba et al. 2009). In INS-1E cells and rat primary $\beta$-cells CHOP contributes to NF- $\mathrm{kB}$ activation by promoting IкB $\alpha$ degradation and subsequent p65 translocation to the nucleus (Fig. 1) (Allagnat et al. 2012). This leads to an increased expression of key NF- $\mathrm{kB}$ target genes involved in apoptosis and inflammation, including iNOS, FAS, IRF7, IL15, CCL5, and CXCL10 (Allagnat et al. 2012). The mechanisms by which CHOP regulates NF- $\mathrm{kB}$ activation are not yet clear. Moreover, the impact of CHOP knockdown in in vivo models of T1D is controversial. Thus, backcrossing NOD mice with Chop $\mathrm{p}^{-/-}$ mice did not prevent or delayed diabetes incidence (Satoh et al. 2011). However, Chop-l- mice are protected against multiple low-dose streptozotocin (MLDSZT)-induced diabetes (Ariyama et al. 2008). The observed protection against MLDSZT, however, suggests that Chop deletion may favor $\beta$-cell survival in a model where inflammation plays a key role, as suggested by the previously described protection afforded by inhibiting NF- $\mathrm{kB}$ expression in $\beta$-cells from MLDSZT-treated mice (Eldor et al. 2006).

In summary, when activated by pro-inflammatory cytokines, the transcription factor NF- $\mathrm{BB}$ regulates UPR responses of $\beta$-cells. However, the UPR positively regulates NF- $\mathrm{kB}$ activity and pro-inflammatory responses, increasing apoptotic signaling and expression of pro-inflammatory cytokines and chemokines that may contribute to $\beta$-cell demise (Fig. 1).

As mentioned above, JNK is another player linking ER stress to inflammation in other cell types. In $\beta$-cells, IL1 $\beta+$ IFN- $\gamma$-mediated JNK activation is partially mediated by IRE1 $\alpha$ (Fig. 1) (Brozzi et al. 2014). Although the proapoptotic role for JNK in $\beta$-cells is well established (Bonny et al. 2001, Nikulina et al. 2003), few studies have evaluated and demonstrated a pro-inflammatory role for JNK in these cells (Hou et al. 2011, Tan et al. 2013, Lawrence et al. 2015). One of the mechanisms by which JNK contributes to ER stress-mediated inflammation in $\beta$-cells is by upregulating CHOP expression (Fig. 1) (Pirot et al. 2007b, Allagnat et al. 2012). Further studies are necessary to evaluate the role of JNK in $\beta$-cell mediatedpro-inflammatory responses.

\section{ER stress, IL1及, and the inflammasome}

Although controversial, it has been proposed that exposure of mouse or human islets to high glucose concentrations induces production of IL1 $\beta$ contributing to $\beta$-cell apoptosis and constitutes a common mechanism for $\beta$-cell death in both T1D and T2D (Cnop et al. 2005, Mandrup-Poulsen et al. 2010). IL1 $\beta$ production is mediated via the NLR family pyrin domain containing 3 (NLRP3) inflammasome, which in turn can be activated via increased expression of TXNIP (Yoshihara et al. 2014). The chemical ER stressor, thapsigargin, was shown to upregulate Txnip mRNA in INS-1E cells, mouse, and human primary islets leading to activation of the NLRP3 inflammasome and release of IL1 $\beta$, contributing to $\beta$-cell death (Lerner et al. 2012, Oslowski et al. 2012). While Txnip induction is directly modulated by PERK (Oslowski et al. 2012), IRE1 $\alpha$ exhibits an indirect effect on Txnip via IRE1 $\alpha$-mediated degradation of a repressive microRNA (Fig. 1) (Lerner et al. 2012). However, a subsequent study failed to observe protection of mouse NLRP3-/- or caspase-1-/- islets against ER stress, glucose, or glucolipotoxicity-mediated cell death (Wali et al. 2014). Moreover, genetic activation of NLRP3 specifically in mouse $\beta$-cells did not induce IL1 $\beta$ expression/production or increased cell death in response to glucolipotoxicity stimuli (Wali et al. 2014). The latter results contradict a role for IL1 $\beta$ or NLRP3 inflammasome in high-glucoseand/or ER stress-mediated $\beta$-cell death and are consistent with other studies that failed to show a role for IL1 $\beta$ under these conditions (Kharroubi et al. 2004, Cnop et al. 2005, McKenzie et al. 2010). Notably, IL1 $\beta$ alone does not induce apoptosis in primary $\beta$-cells (Eizirik \& Mandrup-Poulsen 2001, Cardozo et al. 2005). Therefore, further studies are necessary to clarify the role of ER stress in IL1 $\beta$ production and its involvement in $\beta$-cell death in diabetes.

\section{ER stress and antigen presentation}

In T1D, initiation and progression of the disease is related to the presence of $\beta$-cell-specific autoantibodies (van Belle et al. 2011). Notably, the majority of $\beta$-cell autoantigens recognize proteins produced in the ER (van Belle et al. 2011). Pro-inflammatory cytokines induce both ER stress and assembly of the MHC complex in the organelle (Rasschaert et al. 2003, Cardozo et al. 2005). Therefore, it is plausible that cytokine-mediated UPR could influence post-translational modification of proteins, leading to production and presentation of potential autoantigens. It was previously shown that ER calcium depletion drives the translocation of ER-resident proteins BiP, GRP94, and calreticulin in the plasma membrane (Peters \& Raghavan 2011), which may have pro- or anti-inflammatory outcomes depending on the protein and cellular context (Panayi \& Corrigall 2006, Peters \& Raghavan 2011, Raghavan et al. 2013,

Published by Bioscientifica Ltd 
Pockley et al. 2014). A recent publication showed that cytokines and ER stressors induce translocation of BiP to the plasma membrane in INS-1E, MIN6 cells, and mouse islets (Rondas et al. 2015). Interestingly, proinflammatory cytokines, but not ER stressors, induced BiP citrullination in INS-1E cells (Rondas et al. 2015). Citrullinated BiP induced production of autoantibodies that stimulated effector T-cells in pre-diabetic NOD mice (Fig. 1) (Rondas et al. 2015). The presence of citrullinated proteins correlates with activation of the immune system in autoimmune diseases (Blass et al. 2001, Shoda et al. 2011) and increased response to citrullinated GAD65 peptides is observed in T1D patients (McGinty et al. 2014). Another evidence that ER stress response may influence $\beta$-cell antigen presentation is delayed appearance of autoantibodies observed in NOD mice knockout for Chop (Satoh et al. 2011). However, the mechanism leading to this delayed antibody response was not investigated in this study (Satoh et al. 2011). A recent elegant publication showed that $\beta$-cells transfer antigenic epitopes to antigen presenting cells via a direct membrane contact (Vomund et al. 2015). This is a novel mechanism, however, not specific for 'diabetic' $\beta$-cells, since it was observed in both diabetic and nondiabetic mice and in nondiabetic humans. Interestingly, high glucose increased the transfer of epitopes (Vomund et al. 2015). The mechanism for this increase has not been yet investigated, but it would be interesting to verify whether it is not due to high glucose-induced ER stress. Further work is necessary to clarify the role for ER stress in the process of autoantibody production in patients with T1D and its consequences on $\beta$-cell autoimmunity (Marre et al. 2015).

\section{ER stress-targeting therapies}

As described above, several studies support an important role for ER stress in the pathogenesis of T1D and T2D. Therefore, the development of strategies to prevent or alleviate ER stress in $\beta$-cells may prove useful for prevention and/or treatment of these diseases. Approaches targeting the UPR for therapeutic purposes remain largely in their infancy, but several strategies aimed at improving ER function in pancreatic $\beta$-cells are emerging (Fig. 2).

\section{Targeting the chaperone capacity of the cells}

One strategy to alleviate ER stress in $\beta$-cells relies on the use of chemical chaperones. Two compounds, in particular 4-phenyl butyric acid (4-PBA) and taurine-conjugated ursodeoxycholic acid (TUDCA), show promising results regarding diabetes therapy. As mentioned above, TUDCA administration at the pre-diabetic stage reduces diabetes incidence in the NOD and RIP-LCMV-GP mouse models of T1D and this reduction is accompanied by improved survival and preserved insulin secretion (Engin et al. 2013). In vitro, TUDCA inhibits eIF2 $\alpha$ phosphorylation and restores thapsigargin-induced $\beta$-cell dysfunction in porcine islets (Fig. 2) (Lee et al. 2010), while 4-PBA ameliorates palmitate-induced GSIS inhibition in primary rat islet cells (Choi et al. 2008). Besides $\beta$-cell dysfunction, ER stress also contributes to insulin resistance in T2D (Salvado et al. 2015). Both PBA and TUDCA alleviate ER stress in obese mice, restoring insulin sensitivity and normoglycemia (Ozcan et al. 2006). Importantly, these compounds also improved insulin sensitivity in obese subjects (Kars et al. 2010, Xiao et al. 2011). However, no evidence of improved $\beta$-cell function was provided in these studies and despite these encouraging results, additional research is required to better clarify by which mechanism these compounds are acting, verify their specificity, and explore their long-term benefit and safety.

Another potential strategy is to increase the folding capacity of the ER by enhancing endogenous chaperone expression in $\beta$-cells. Valproic acid (VPA), a drug widely used for the treatment of epilepsy and mood disorders (Chen et al. 2014), has been shown to increase the expression of $\mathrm{BiP}$, reduce expression of $\mathrm{CHOP}$, and protect from ER stress-induced neuronal cell death in various rat models (Fig. 2) (Wang et al. 1999, Bown et al. 2002, Penas et al. 2011, Zhang et al. 2011, Lee et al. 2014). Interestingly, Huang et al. recently demonstrated that VPA protects rat INS-1 cells from palmitate-induced ER stress and apoptosis via GSK-3 $\beta$ inhibition, independent of ATF4/CHOP pathway (Huang et al. 2014). Notably, GSK $\beta 3$ inhibition also protects $\beta$-cells against both chemical ER stress- and cytokine-mediated $\beta$-cell apoptosis (Srinivasan et al. 2005, Fukaya et al. 2016). One of the possible mechanisms could be stabilization of the anti-apoptotic protein MCL1, since inhibition of GSK3 $\beta$ hampers cytokine-mediated MCL1 degradation and protects INS-1E and human $\beta$-cells against apoptosis (Meyerovich K, Ortis F, Allagnat F and Cardozo AK unpublished observations). Further studies are required to extend these findings in animal models and explore the potential efficacy of VPA and/or GSK3 $\beta$ inhibition on $\beta$-cell death in vivo.

Studies carried out in neuronal cells suggest that the BiP inducer $\mathrm{X}$ (BIX) compound protects against ER stress-induced neuronal cell death in mice (Fig. 2)

Published by Bioscientifica Ltd. 


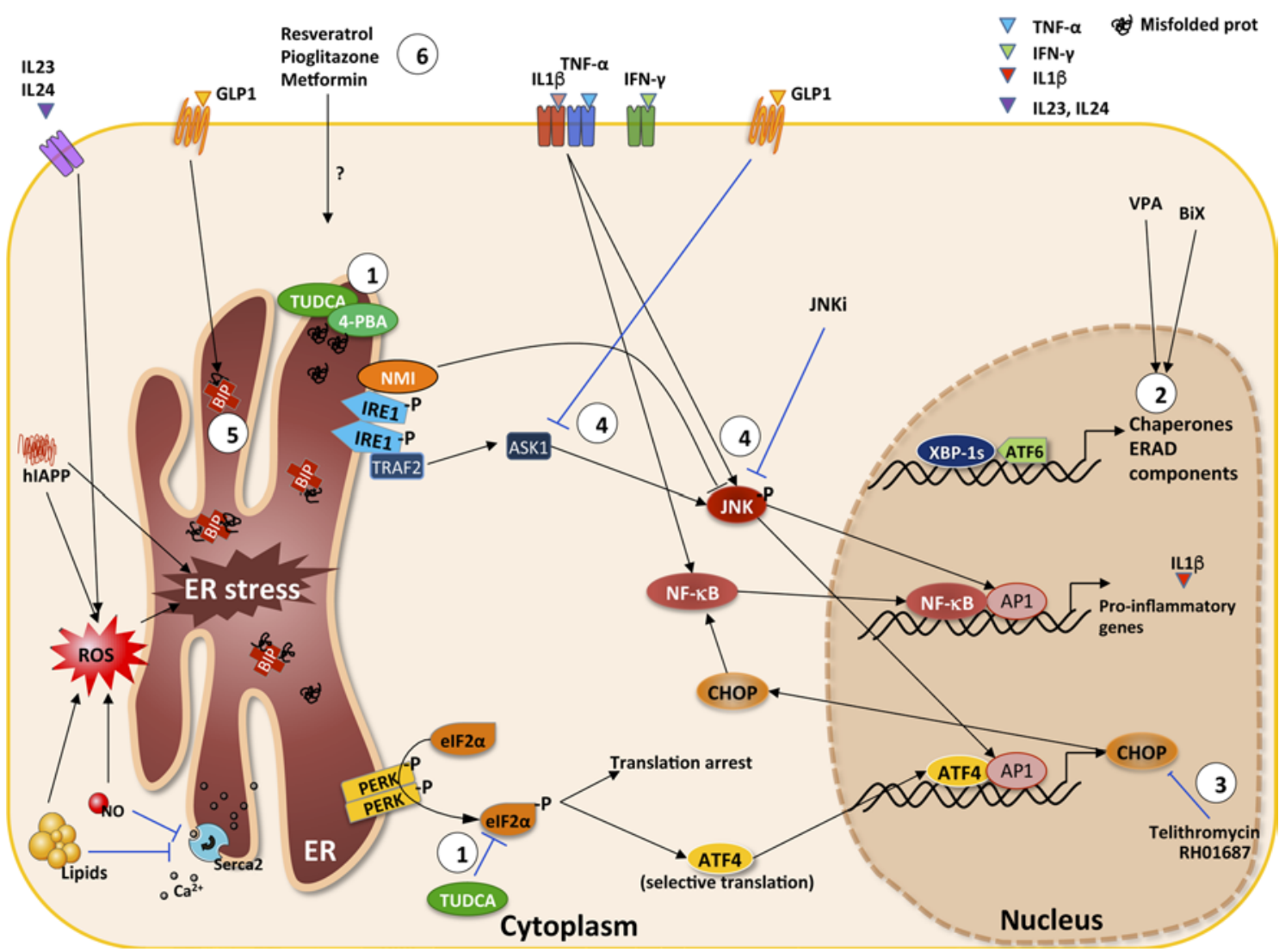

Figure 2

ER stress-targeting therapies. Several strategies to improve ER function in pancreatic $\beta$-cells are emerging. (1) The use of the chemical chaperones 4-phenyl butyric acid (4-PBA) and taurine-conjugated ursodeoxycholic acid (TUDCA) show promising results regarding diabetes therapy, although their mode of action remains largely unknown. (2) Several compounds such as valproic acid (VPA) or BiP inducer X (BiX) may promote the expression of endogenous chaperones, thereby reducing ER stress and apoptosis. (3) Two novel compounds, namely telithromycin and RH01687, were shown to inhibit CHOP and promote $\beta$-cell function and survival during ER stress. (4) Strategies aimed at blocking pro-apoptotic UPR pathway such as ASK1 or JNK activity downstream of IRE $1 \alpha$ have been shown to protect against ER stress-mediated cell death. Notably, the anti-apoptotic properties of GLP1 are partly mediated by reduced ER stress through actions on ASK1 and the transcription factor JunB downstream JNK (5). GLP1 may also stimulate BiP expression. (6) Finally, other anti-diabetic therapies such as pioglitazone, metformin, or resveratrol have been shown to reduce ER stress in $\beta$-cells through unknown mechanisms.

(Kudo et al. 2008, Inokuchi et al. 2009). Whether or not this compound might be of interest for the treatment of diabetes, in general, and the survival of pancreatic $\beta$-cells, in particular, remains to be assessed.

\section{Targeting the UPR}

The PERK-eIF2 $\alpha$ pathway plays a central role in the UPR pro-apoptotic signaling (Laybutt et al. 2007, Song et al. 2008, Allagnat et al. 2012). Thus, salubrinal, a compound preventing eIF2 $\alpha$ dephosphorylation and driving CHOP expression, increases the sensitivity of rat and human pancreatic $\beta$-cells to fatty-acid-induced ER stress and apoptosis (Cnop et al. 2007, Ladriere et al. 2010). Moreover, upregulation of CHOP and downregulation of the anti-apoptotic protein MCL1 contributes to ER stress-mediated $\beta$-cell apoptosis downstream of PERK (Laybutt et al. 2007, Allagnat et al. 2012). Therefore, compounds that prevent eIF2 $\alpha$ phosphorylation and subsequently CHOP expression might prove useful for the treatment of diabetes. However, salubrinal protects neuronal cells from ER stress-induced cell death (Boyce et al. 2005, Fullwood et al. 2012), suggesting the need for cell-specific therapies when targeting UPR pathways. Recently, the screening of a bank of compounds identify telithromycin and RH01687 as potential anti-apoptotic molecules targeting CHOP and reducing tunicamycininduced apoptosis and restoring the insulin secretion in vitro in $\beta$ TC6 and MIN6 (Fig. 2) (Tran et al. 2014). Further studies are necessary to extend those findings in primary cells and in vivo and test whether such molecules do not have adverse effects on other organs.

Published by Bioscientifica Ltd. 
Another possibility to block CHOP expression is to act on another upstream regulator, that is, JNK (Allagnat et al. 2012, Gurzov et al. 2012). As mentioned above, the kinase JNK plays a central role in ER stress and pancreatic $\beta$-cell dysfunction (Bonny et al. 2001, Nikulina et al. 2003). Besides CHOP, JNK may activate other pro-apoptotic proteins such as BID, BIM, and death protein 5 (DP5), while inhibiting anti-apoptotic proteins such as BCL2 and MCL1 (Dhanasekaran \& Reddy 2008, Gurzov et al. 2009, Allagnat et al. 2011, Santin et al. 2011). Moreover, JNK activation resulting from ER stress contributes to insulin resistance in insulin-stimulated cells and organs, such as liver and adipose tissue (Kaneto et al. 2006). Therefore, compounds targeting JNK activation may have a positive impact on multiple organs in the context of T2D. The cellpermeable peptide inhibitor of JNK (Fig. 2) (1) prevents islet apoptosis after isolation (Noguchi et al. 2005), (2) improves islet grafts survival (Noguchi et al. 2008), and (3) prevents ER stress-induced CHOP expression in rat INS-1E cells (Allagnat et al. 2012, Gurzov et al. 2012). Further studies are required to test the potential of this JNK inhibitor in vivo.

Cytokine-induced JNK activation is at least partially mediated via the IRE1 $\alpha$ pathway. However, targeting IRE1 $\alpha$ is not ideal since this protein is also responsible for activation of Xbp1- and Ire $1 \alpha$-knockout mice are not viable (Zhang et al. 2005). The best alternative is to interfere with IRE1 $\alpha$ downstream signaling leading to JNK activation. It was recently shown that N-MYC interactor (NMI) protein negatively modulates IRE1 $\alpha$-dependent activation of JNK and apoptosis in rodent and human pancreatic $\beta$-cells (Brozzi et al. 2014), thus NMI could be pointed as a potential target. IRE1-mediated JNK activation is also downstream of the apoptosis signal-regulated kinase 1 protein (ASK1). Interestingly, ASK1 is activated by ER stress in MIN6 cells in vitro and ASK1 deficiency in vivo decreases $\beta$-cell apoptosis and delays the onset of diabetes in Akita mice (Yamaguchi et al. 2013). Therefore, chemical inhibitors of ASK1 might provide cytoprotection in the context of ER stress.

\section{Existing treatments of T2D that reduce ER stress}

One of the most promising avenues for the treatment of diabetes relies on GLP1 receptor agonists such as liraglutide and exenatide (reviewed in (Madsbad 2016)) and inhibitors of the dipeptidyl peptidase-4 (DPP4) peptidase responsible for rapid degradation of GLP1 (reviewed in Li et al. 2015, Deacon \& Lebovitz 2016, Nauck 2016). The anti-apoptotic properties of GLP1 in $\beta$-cells are well known and they are at least partially mediated by reduced ER stress through actions on several targets including BiP, ASK1, SIRT1, and the transcription factors C/EBPs and JunB (Fig. 2) (Yusta et al. 2006, Tsunekawa et al. 2007, Cunha et al. 2009, Kwon et al. 2009, Widenmaier et al. 2009, Oh et al. 2013, Kim et al. 2015).

Other existing treatments of T2D such as the insulin sensitizers Metformin and Pioglitazone are known to improve insulin sensitivity partly by reducing ER stress in the liver and peripheral tissues (Fig. 2) (Singh et al. 2015). Pioglitazone was recently shown to reduce ER stress in Wfs1-deficient mice (Yamada et al. 2006), a genetic model for ER stress-mediated $\beta$-cell loss and diabetes, thus almost preventing the onset of diabetes in those mice (Akiyama et al. 2009). Pioglitazone also protects rat insulin-secreting cells from thapsigargin-induced cell death (Hara et al. 2014). Similarly, Metformin partially protects INS-1 cells from palmitate-induced ER stress and cell death (Simon-Szabo et al. 2014). The fact that current T2D therapies act, at least partly, through modulation of UPR pathways underscores the central role of ER stress in $\beta$-cell dysfunction and death.

An array of additional molecules with anti-oxidant properties improve several circulating markers of T2D such as fasting blood glucose, HbA1c, insulin, and lipid (LDL and triglycerides) levels (Azadmehr et al. 2014, Szkudelski \& Szkudelska 2015). Among them resveratrol was shown to protect against ER stress-driven cell dysfunction in the context of obesity-related disorders and diabetes (Andrade et al. 2014, Guo et al. 2015). However, further studies are required to better characterize the molecular mechanisms regulating the effects of resveratrol in $\beta$-cells.

\section{Conclusions}

Research on the UPR is a relatively new field and although its role on $\beta$-cell function, dysfunction, and survival is well studied, the role of the UPR in $\beta$-cell pro-inflammatory responses is just beginning to be elucidated. Thus, 'sterile' (non-inflammatory/chemically induced) UPR activation is able to induce pro-inflammatory responses in $\beta$-cells. However, $\beta$-cell exposure to pro-inflammatory cytokines released in and from the islets in both T1D and T2D induces UPR responses that in turn may potentiate inflammation and contribute to $\beta$-cell death. The mechanisms by which the UPR modulates inflammation are not completely clarified, but the available data indicates that it is context-dependent. Recent studies showing that manipulating UPR responses may decrease inflammatory responses and reduced diabetes developments in animal models of both T1D and T2D indicate that these

Published by Bioscientifica Ltd. 
pathways are of relevance and can be used as new targets for interventional therapies to prevent these diseases.

As discussed in this article, ER stress and disrupted UPR are likely to play a central role in the pathophysiology of diabetes, not only at the $\beta$-cell level, but also in the liver, muscle, adipose tissue, and immune system. Therefore, approaches aimed at reducing ER stress might have beneficial effects on multiple organs. However, one should keep in mind that certain strategies to protect $\beta$-cells might have detrimental effects in other tissues. The studies indicating that current therapies for treating T2D alleviate ER stress and the fact that existing molecules already used to treat other pathologies may also reduce ER stress in $\beta$-cells provide exciting opportunities to advance the treatment of diabetes.

\section{Declaration of interest}

The authors declare that there is no conflict of interest that could be perceived as prejudicing the impartiality of this review.

\section{Funding}

A.K.C. group's work was supported by the Juvenile Diabetes Research Foundation (JDRF-New York-USA; 1-2011-589), Actions de Recherché Concertées de la Communauté Française (ARC - Belgium; 20063), and National Funds from Scientific Research (FNRS, Belgium; F.4521.11). Research of F.O. is financed by Fundação de Auxilio a Pesquisa do Estado de São Paulo (FAPESP; 2010/05587-1). F.A. is supported by the Swiss National Fund (SNF 31003A-155897)

\section{References}

Akiyama M, Hatanaka M, Ohta Y, Ueda K, Yanai A, Uehara Y, Tanabe K, Tsuru M, Miyazaki M, Saeki S, et al. 2009 Increased insulin demand promotes while pioglitazone prevents pancreatic beta cell apoptosis in Wfs1 knockout mice. Diabetologia 52 653-663. (doi:10.1007/ s00125-009-1270-6)

Allagnat F, Christulia F, Ortis F, Pirot P, Lortz S, Lenzen S, Eizirik DL \& Cardozo AK 2010 Sustained production of spliced X-box binding protein 1 (XBP1) induces pancreatic beta cell dysfunction and apoptosis. Diabetologia 53 1120-1130. (doi:10.1007/s00125-0101699-7)

Allagnat F, Cunha D, Moore F, Vanderwinden JM, Eizirik DL \& Cardozo AK 2011 Mcl-1 downregulation by pro-inflammatory cytokines and palmitate is an early event contributing to beta-cell apoptosis. Cell Death and Differentiation 18 328-337. (doi:10.1038/ cdd.2010.105)

Allagnat F, Fukaya M, Nogueira TC, Delaroche D, Welsh N, Marselli L, Marchetti P, Haefliger JA, Eizirik DL \& Cardozo AK 2012 C/EBP homologous protein contributes to cytokine-induced proinflammatory responses and apoptosis in beta-cells. Cell Death and Differentiation 19 1836-1846. (doi:10.1038/cdd.2012.67)

Andrade JM, Paraiso AF, de Oliveira MV, Martins AM, Neto JF, Guimaraes AL, de Paula AM, Qureshi M \& Santos SH 2014 Resveratrol attenuates hepatic steatosis in high-fat fed mice by decreasing lipogenesis and inflammation. Nutrition 30 915-919. (doi:10.1016/j.nut.2013.11.016)
Angel P, Szabowski A \& Schorpp-Kistner M 2001 Function and regulation of AP-1 subunits in skin physiology and pathology. Oncogene 20 2413-2423. (doi:10.1038/sj.onc.1204380)

Ariyama Y, Tanaka Y, Shimizu H, Shimomura K, Okada S, Saito T, Yamada E, Oyadomari S \& Mori M 2008 The role of CHOP messenger RNA expression in the link between oxidative stress and apoptosis. Metabolism 57 1625-1635. (doi:10.1016/j. metabol.2008.06.019)

Azadmehr A, Ziaee A, Ghanei L, Fallah Huseini H, Hajiaghaee R, Tavakoli-Far B \& Kordafshari G 2014 A randomized clinical trial study: anti-oxidant, anti-hyperglycemic and anti-hyperlipidemic effects of olibanum gum in type 2 diabetic patients. Iranian Journal of Pharmaceutical Research 13 1003-1009.

Back SH, Scheuner D, Han J, Song B, Ribick M, Wang J, Gildersleeve RD, Pennathur S \& Kaufman RJ 2009 Translation attenuation through eIF2alpha phosphorylation prevents oxidative stress and maintains the differentiated state in beta cells. Cell Metabolism 10 13-26. (doi:10.1016/j.cmet.2009.06.002)

Blass S, Union A, Raymackers J, Schumann F, Ungethum U, MullerSteinbach S, De Keyser F, Engel JM \& Burmester GR 2001 The stress protein BiP is overexpressed and is a major B and $\mathrm{T}$ cell target in rheumatoid arthritis. Arthritis and Rheumatism 44 761-771.

Bonny C, Oberson A, Negri S, Sauser C \& Schorderet DF 2001 Cell-permeable peptide inhibitors of JNK: novel blockers of beta-cell death. Diabetes 50 77-82. (doi:10.2337/diabetes.50.1.77)

Bown CD, Wang JF, Chen B \& Young LT 2002 Regulation of ER stress proteins by valproate: therapeutic implications. Bipolar Disorders 4 145-151. (doi:10.1034/j.1399-5618.2002.t01-1-40201.x)

Boyce M, Bryant KF, Jousse C, Long K, Harding HP, Scheuner D, Kaufman RJ, Ma D, Coen DM, Ron D, et al. 2005 A selective inhibitor of eIF2alpha dephosphorylation protects cells from ER stress. Science $\mathbf{3 0 7}$ 935-939. (doi:10.1126/science.1101902)

Brozzi F \& Eizirik DL 2016 ER stress and the decline and fall of pancreatic beta cells in type 1 diabetes. Upsala Journal of Medical Sciences 1-7. (doi:10.3109/03009734.2015.1135217)

Brozzi F, Gerlo S, Grieco FA, Nardelli TR, Lievens S, Gysemans C, Marselli L, Marchetti P, Mathieu C, Tavernier J, et al. 2014 A combined 'omics' approach identifies N-Myc interactor as a novel cytokine-induced regulator of IRE1 protein and c-Jun N-terminal kinase in pancreatic beta cells. Journal of Biological Chemistry 289 20677-20693. (doi:10.1074/jbc.M114.568808)

Brozzi F, Nardelli TR, Lopes M, Millard I, Barthson J, Igoillo-Esteve M, Grieco FA, Villate O, Oliveira JM, Casimir M, et al. 2015 Cytokines induce endoplasmic reticulum stress in human, rat and mouse beta cells via different mechanisms. Diabetologia 58 2307-2316. (doi:10.1007/s00125-015-3669-6)

Cao SS \& Kaufman RJ 2014 Endoplasmic reticulum stress and oxidative stress in cell fate decision and human disease. Antioxidants \& Redox Signaling 21 396-413. (doi:10.1089/ars.2014.5851)

Cardozo AK, Ortis F, Storling J, Feng YM, Rasschaert J, Tonnesen M, Van Eylen F, Mandrup-Poulsen T, Herchuelz A \& Eizirik DL 2005 Cytokines downregulate the sarcoendoplasmic reticulum pump Ca2+ ATPase $2 \mathrm{~b}$ and deplete endoplasmic reticulum $\mathrm{Ca} 2+$, leading to induction of endoplasmic reticulum stress in pancreatic beta-cells. Diabetes 54 452-461. (doi:10.2337/diabetes.54.2.452)

Chan JY, Cooney GJ, Biden TJ \& Laybutt DR 2011 Differential regulation of adaptive and apoptotic unfolded protein response signalling by cytokine-induced nitric oxide production in mouse pancreatic beta cells. Diabetologia 54 1766-1776. (doi:10.1007/s00125-011-2139-z)

Chan JY, Biden TJ \& Laybutt DR 2012 Cross-talk between the unfolded protein response and nuclear factor-kappaB signalling pathways regulates cytokine-mediated beta cell death in MIN6 cells and isolated mouse islets. Diabetologia 55 2999-3009. (doi:10.1007/ s00125-012-2657-3)

Chaudhari N, Talwar P, Parimisetty A, Lefebvre d'Hellencourt C \& Ravanan P 2014 A molecular web: endoplasmic reticulum stress,

Published by Bioscientifica Ltd. 
inflammation, and oxidative stress. Frontiers in Cellular Neuroscience 8 213. (doi:10.3389/fncel.2014.00213)

Chen S, Wu H, Klebe D, Hong Y \& Zhang J 2014 Valproic acid: a new candidate of therapeutic application for the acute central nervous system injuries. Neurochemical Research 39 1621-1633. (doi:10.1007/ s11064-014-1241-2)

Choi SE, Lee YJ, Jang HJ, Lee KW, Kim YS, Jun HS, Kang SS, Chun J \& Kang Y 2008 A chemical chaperone 4-PBA ameliorates palmitateinduced inhibition of glucose-stimulated insulin secretion (GSIS). Archives of Biochemistry and Biophysics 475 109-114. (doi:10.1016/j. abb.2008.04.015)

Christoffersson G, Rodriguez-Calvo T \& von Herrath M 2016 Recent advances in understanding type 1 diabetes. F1000Research $\mathbf{5}$ pii: F1000. (doi:10.12688/f1000research.7356.1)

Cnop M, Welsh N, Jonas JC, Jorns A, Lenzen S \& Eizirik DL 2005 Mechanisms of pancreatic beta-cell death in type 1 and type 2 diabetes: many differences, few similarities. Diabetes $\mathbf{5 4}$ (Supplement 2) S97-S107.

Cnop M, Ladriere L, Hekerman P, Ortis F, Cardozo AK, Dogusan Z, Flamez D, Boyce M, Yuan J \& Eizirik DL 2007 Selective inhibition of eukaryotic translation initiation factor 2 alpha dephosphorylation potentiates fatty acid-induced endoplasmic reticulum stress and causes pancreatic beta-cell dysfunction and apoptosis. Journal of Biological Chemistry 282 3989-3997. (doi:10.1074/jbc.M607627200)

Cnop M, Ladriere L, Igoillo-Esteve M, Moura RF \& Cunha DA 2010 Causes and cures for endoplasmic reticulum stress in lipotoxic betacell dysfunction. Diabetes, Obesity and Metabolism 12 (Supplement 2) 76-82. (doi:10.1111/j.1463-1326.2010.01279.x)

Colombo C, Porzio O, Liu M, Massa O, Vasta M, Salardi S, Beccaria L, Monciotti C, Toni S, Pedersen O, et al. 2008 Seven mutations in the human insulin gene linked to permanent neonatal/ infancy-onset diabetes mellitus. Journal of Clinical Investigation 118 2148-2156. (doi:10.1172/JCI33777)

Cucak H, Mayer C, Tonnesen M, Thomsen LH, Grunnet LG \& Rosendahl A 2014 Macrophage contact dependent and independent TLR4 mechanisms induce beta-cell dysfunction and apoptosis in a mouse model of type 2 diabetes. PLOS ONE 9 e90685. (doi:10.1371/ journal.pone.0090685)

Cucinotta M, Visalli M, Aguennouz M, Valenti A, Loddo S, Altucci L \& Teti D 2008 Regulation of interleukin-8 gene at a distinct site of its promoter by CCAAT enhancer-binding protein homologous protein in prostaglandin E2-treated human T cells. Journal of Biological Chemistry 283 29760-29769. (doi:10.1074/jbc.M803145200)

Cullinan SB \& Diehl JA 2006 Coordination of ER and oxidative stress signaling: the PERK/Nrf2 signaling pathway. International Journal of Biochemistry and Cell Biology 38 317-332. (doi:10.1016/j. biocel.2005.09.018)

Cunha DA, Hekerman P, Ladriere L, Bazarra-Castro A, Ortis F, Wakeham MC, Moore F, Rasschaert J, Cardozo AK, Bellomo E, et al. 2008 Initiation and execution of lipotoxic ER stress in pancreatic beta-cells. Journal of Cell Science 121 2308-2318. (doi:10.1242/ jcs.026062)

Cunha DA, Ladriere L, Ortis F, Igoillo-Esteve M, Gurzov EN, Lupi R, Marchetti P, Eizirik DL \& Cnop M 2009 Glucagon-like peptide-1 agonists protect pancreatic beta-cells from lipotoxic endoplasmic reticulum stress through upregulation of BiP and JunB. Diabetes 58 2851-2862. (doi:10.2337/db09-0685)

Davis RJ 2000 Signal transduction by the JNK group of MAP kinases. Cell 103 239-252. (doi:10.1016/S0092-8674(00)00116-1)

Deacon CF \& Lebovitz HE 2016 Comparative review of dipeptidyl peptidase-4 inhibitors and sulphonylureas. Diabetes, Obesity and Metabolism 18 333-347. (doi:10.1111/dom.12610)

Delepine M, Nicolino M, Barrett T, Golamaully M, Lathrop GM \& Julier C 2000 EIF2AK3, encoding translation initiation factor 2-alpha kinase 3, is mutated in patients with Wolcott-Rallison syndrome. Nature Genetics 25 406-409. (doi:10.1038/78085)
Deng J, Lu PD, Zhang Y, Scheuner D, Kaufman RJ, Sonenberg N, Harding HP \& Ron D 2004 Translational repression mediates activation of nuclear factor kappa B by phosphorylated translation initiation factor 2. Molecular and Cellular Biology 24 10161-10168. (doi:10.1128/MCB.24.23.10161-10168.2004)

DeZwaan-McCabe D, Riordan JD, Arensdorf AM, Icardi MS, Dupuy AJ \& Rutkowski DT 2013 The stress-regulated transcription factor CHOP promotes hepatic inflammatory gene expression, fibrosis, and oncogenesis. PLoS Genetics 9 e1003937. (doi:10.1371/journal. pgen.1003937)

Dhanasekaran DN \& Reddy EP 2008 JNK signaling in apoptosis. Oncogene 27 6245-6251. (doi:10.1038/onc.2008.301)

Duncan BB, Schmidt MI, Pankow JS, Ballantyne CM, Couper D, Vigo A, Hoogeveen R, Folsom AR, Heiss G \& Atherosclerosis Risk in Communities Study 2003 Low-grade systemic inflammation and the development of type 2 diabetes: the atherosclerosis risk in communities study. Diabetes 52 1799-1805. (doi:10.2337/ diabetes.52.7.1799)

Eferl R \& Wagner EF 2003 AP-1: a double-edged sword in tumorigenesis. Nature Reviews Cancer 3 859-868. (doi:10.1038/nrc1209)

Eguchi K \& Manabe I 2013 Macrophages and islet inflammation in type 2 diabetes. Diabetes, Obesity and Metabolism 15 (Supplement 3) 152-158. (doi:10.1111/dom.12168)

Eguchi K, Manabe I, Oishi-Tanaka Y, Ohsugi M, Kono N, Ogata F, Yagi N, Ohto U, Kimoto M, Miyake K, et al. 2012 Saturated fatty acid and TLR signaling link beta cell dysfunction and islet inflammation. Cell Metabolism 15 518-533. (doi:10.1016/j.cmet.2012.01.023)

Eizirik DL 1991 Interleukin-1 beta induces an early decrease in insulin release, (pro)insulin biosynthesis and insulin mRNA in mouse pancreatic islets by a mechanism dependent on gene transcription and protein synthesis. Autoimmunity 10 107-113. (doi:10.3109/08916939109004814)

Eizirik DL \& Mandrup-Poulsen T 2001 A choice of death - the signaltransduction of immune-mediated beta-cell apoptosis. Diabetologia 44 2115-2133. (doi:10.1007/s001250100021)

Eizirik DL, Cardozo AK \& Cnop M 2008 The role for endoplasmic reticulum stress in diabetes mellitus. Endocrine Reviews 29 42-61. (doi:10.1210/er.2007-0015)

Eizirik DL, Colli ML \& Ortis F 2009 The role of inflammation in insulitis and beta-cell loss in type 1 diabetes. Nature Reviews Endocrinology 5 219-226. (doi:10.1038/nrendo.2009.21)

Eldor R, Yeffet A, Baum K, Doviner V, Amar D, Ben-Neriah Y, Christofori G, Peled A, Carel JC, Boitard C, et al. 2006 Conditional and specific NF-kappaB blockade protects pancreatic beta cells from diabetogenic agents. PNAS 103 5072-5077. (doi:10.1073/ pnas.0508166103)

Ellgaard L \& Helenius A 2003 Quality control in the endoplasmic reticulum. Nature Reviews in Molecular Cell Biology 4 181-191. (doi:10.1038/nrm1052)

Elouil H, Bensellam M, Guiot Y, Vander Mierde D, Pascal SM, Schuit FC \& Jonas JC 2007 Acute nutrient regulation of the unfolded protein response and integrated stress response in cultured rat pancreatic islets. Diabetologia 50 1442-1452. (doi:10.1007/s00125-007-0674-4)

Endo M, Oyadomari S, Suga M, Mori M \& Gotoh T 2005 The ER stress pathway involving CHOP is activated in the lungs of LPS-treated mice. Journal of Biochemistry 138 501-507. (doi:10.1093/jb/mvi143)

Endo M, Mori M, Akira S \& Gotoh T 2006 C/EBP homologous protein (CHOP) is crucial for the induction of caspase-11 and the pathogenesis of lipopolysaccharide-induced inflammation. Journal of Immunology 176 6245-6253. (doi:10.4049/jimmunol.176.10.6245)

Engin F, Yermalovich A, Ngyuen T, Hummasti S, Fu W, Eizirik DL, Mathis D \& Hotamisligil GS 2013 Restoration of the unfolded protein response in pancreatic beta cells protects mice against type 1 diabetes. Science Translational Medicine 5 211ra156. (doi:10.1126/ scitranslmed.3006534)

Published by Bioscientifica Ltd. 
Fukaya M, Brorsson CA, Meyerovich K, Catrysse L, Delaroche D, Vanzela EC, Ortis F, Beyaert R, Nielsen LB, Andersen ML, et al. 2016 A20 Inhibits beta-cell apoptosis by multiple mechanisms and predicts residual beta-cell function in type 1 diabetes. Molecular Endocrinology 30 48-61. (doi:10.1210/me.2015-1176)

Fullwood MJ, Zhou W \& Shenolikar S 2012 Targeting phosphorylation of eukaryotic initiation factor-2alpha to treat human disease. Progress in Molecular Biology and Translational Science 106 75-106. (doi:10.1016/B978-0-12-396456-4.00005-5)

Garg AD, Kaczmarek A, Krysko O, Vandenabeele P, Krysko DV \& Agostinis P 2012 ER stress-induced inflammation: does it aid or impede disease progression? Trends in Molecular Medicine 18 589-598. (doi:10.1016/j.molmed.2012.06.010)

Gargalovic PS, Gharavi NM, Clark MJ, Pagnon J, Yang WP, He A, Truong A, Baruch-Oren T, Berliner JA, Kirchgessner TG, et al. 2006 The unfolded protein response is an important regulator of inflammatory genes in endothelial cells. Arteriosclerosis, Thrombosis, and Vascular Biology 26 2490-2496. (doi:10.1161/01. ATV.0000242903.41158.a1)

Gomez E, Powell ML, Bevington A \& Herbert TP 2008 A decrease in cellular energy status stimulates PERK-dependent eIF2alpha phosphorylation and regulates protein synthesis in pancreatic betacells. Biochemical Journal 410 485-493. (doi:10.1042/BJ20071367)

Gorman AM, Healy SJ, Jager R \& Samali A 2012 Stress management at the ER: regulators of ER stress-induced apoptosis. Pharmacology \& Therapeutics 134 306-316. (doi:10.1016/j.pharmthera.2012.02.003)

Grieco FA, Vendrame F, Spagnuolo I \& Dotta F 2011 Innate immunity and the pathogenesis of type 1 diabetes. Seminars in Immunopathology 33 57-66. (doi:10.1007/s00281-010-0206-z)

Grossmann V, Schmitt VH, Zeller T, Panova-Noeva M, Schulz A, LaubertReh D, Juenger C, Schnabel RB, Abt TG, Laskowski R, et al. 2015 Profile of the immune and inflammatory response in individuals with prediabetes and type 2 diabetes. Diabetes Care 38 1356-1364. (doi:10.2337/dc14-3008)

Guo R, Liu W, Liu B, Zhang B, Li W \& Xu Y 2015 SIRT1 suppresses cardiomyocyte apoptosis in diabetic cardiomyopathy: an insight into endoplasmic reticulum stress response mechanism. International Journal of Cardiology 191 36-45. (doi:10.1016/j.ijcard.2015.04.245)

Gurzov EN \& Eizirik DL 2011 Bcl-2 proteins in diabetes: mitochondrial pathways of beta-cell death and dysfunction. Trends in Cell Biology 21 424-431. (doi:10.1016/j.tcb.2011.03.001)

Gurzov EN, Ortis F, Cunha DA, Gosset G, Li M, Cardozo AK \& Eizirik DL 2009 Signaling by IL-1beta+IFN-gamma and ER stress converge on DP5/Hrk activation: a novel mechanism for pancreatic beta-cell apoptosis. Cell Death and Differentiation 16 1539-1550. (doi:10.1038/ cdd.2009.99)

Gurzov EN, Barthson J, Marhfour I, Ortis F, Naamane N, IgoilloEsteve M, Gysemans C, Mathieu C, Kitajima S, Marchetti P, et al. 2012 Pancreatic beta-cells activate a JunB/ATF3-dependent survival pathway during inflammation. Oncogene 31 1723-1732. (doi:10.1038/onc.2011.353)

Haataja L, Gurlo T, Huang CJ \& Butler PC 2008 Islet amyloid in type 2 diabetes, and the toxic oligomer hypothesis. Endocrine Reviews 29 303-316. (doi:10.1210/er.2007-0037)

Han D, Lerner AG, Vande Walle L, Upton JP, Xu W, Hagen A, Backes BJ, Oakes SA \& Papa FR 2009 IRE1alpha kinase activation modes control alternate endoribonuclease outputs to determine divergent cell fates. Cell 138 562-575. (doi:10.1016/j.cell.2009.07.017)

Hara T, Mahadevan J, Kanekura K, Hara M, Lu S \& Urano F 2014 Calcium efflux from the endoplasmic reticulum leads to beta-cell death. Endocrinology 155 758-768. (doi:10.1210/en.2013-1519)

Hara M, Fowler JL, Bell GI \& Philipson LH 2016 Resting beta-cells a functional reserve? Diabetes \& Metabolism [in press]. (doi:10.1016/j. diabet.2016.01.001)

Harding HP, Zhang Y, Zeng H, Novoa I, Lu PD, Calfon M, Sadri N, Yun C, Popko B, Paules R, et al. 2003 An integrated stress response regulates amino acid metabolism and resistance to oxidative stress. Molecular Cell 11 619-633. (doi:10.1016/S1097-2765(03)00105-9)

Hasnain SZ, Borg DJ, Harcourt BE, Tong H, Sheng YH, Ng CP, Das I, Wang R, Chen AC, Loudovaris T, et al. 2014 Glycemic control in diabetes is restored by therapeutic manipulation of cytokines that regulate beta cell stress. Nature Medicine 20 1417-1426. (doi:10.1038/ nm.3705)

Hasnain SZ, Prins JB \& McGuckin MA 2016 Oxidative and endoplasmic reticulum stress in beta-cell dysfunction in diabetes. Journal of Molecular Endocrinology 56 R33-R54. (doi:10.1530/JME-15-0232)

Hassler JR, Scheuner DL, Wang S, Han J, Kodali VK, Li P, Nguyen J, George JS, Davis C, Wu SP, et al. 2015 The IRE1alpha/XBP1s pathway is essential for the glucose response and protection of beta cells. PLoS Biology 13 e1002277. (doi:10.1371/journal.pbio.1002277)

Hetz C 2012 The unfolded protein response: controlling cell fate decisions under ER stress and beyond. Nature Reviews in Molecular Cell Biology 13 89-102. (doi:10.1038/nrm3270)

Hotamisligil GS 2010 Endoplasmic reticulum stress and the inflammatory basis of metabolic disease. Cell 140 900-917. (doi:10.1016/j.cell.2010.02.034)

Hou ZQ, Li HL, Gao L, Pan L, Zhao JJ \& Li GW 2008 Involvement of chronic stresses in rat islet and INS-1 cell glucotoxicity induced by intermittent high glucose. Molecular and Cellular Endocrinology 291 71-78. (doi:10.1016/j.mce.2008.03.004)

Hou X, Wang O, Li Z, Mou H, Chen J, Deng B, Qian L, Liu X \& Le Y 2011 Upregulation of pancreatic derived factor (FAM3B) expression in pancreatic beta-cells by MCP-1 (CCL2). Molecular and Cellular Endocrinology 343 18-24. (doi:10.1016/j.mce.2011.05.039)

Hu P, Han Z, Couvillon AD, Kaufman RJ \& Exton JH 2006 Autocrine tumor necrosis factor alpha links endoplasmic reticulum stress to the membrane death receptor pathway through IRE1alpha-mediated NF-kappaB activation and down-regulation of TRAF2 expression. Molecular and Cellular Biology 26 3071-3084. (doi:10.1128/ MCB.26.8.3071-3084.2006)

Hu F, Yu X, Wang H, Zuo D, Guo C, Yi H, Tirosh B, Subjeck JR, Qiu X \& Wang XY 2011 ER stress and its regulator X-box-binding protein-1 enhance polyIC-induced innate immune response in dendritic cells. European Journal of Immunology 41 1086-1097. (doi:10.1002/ eji.201040831)

Huang CJ, Lin CY, Haataja L, Gurlo T, Butler AE, Rizza RA \& Butler PC 2007 High expression rates of human islet amyloid polypeptide induce endoplasmic reticulum stress mediated beta-cell apoptosis, a characteristic of humans with type 2 but not type 1 diabetes. Diabetes 56 2016-2027. (doi:10.2337/db07-0197)

Huang S, Zhu M, Wu W, Rashid A, Liang Y, Hou L, Ning Q \& Luo X 2014 Valproate pretreatment protects pancreatic beta-cells from palmitate-induced ER stress and apoptosis by inhibiting glycogen synthase kinase-3beta. Journal of Biomedical Science 2138. (doi:10.1186/1423-0127-21-38)

Huang H, Jing G, Wang JJ, Sheibani N \& Zhang SX 2015 ATF4 is a novel regulator of MCP-1 in microvascular endothelial cells. Journal of Inflammation 12 31. (doi:10.1186/s12950-015-0076-1)

Hybertson BM, Gao B, Bose SK \& McCord JM 2011 Oxidative stress in health and disease: the therapeutic potential of Nrf2 activation. Molecular Aspects of Medicine 32 234-246. (doi:10.1016/j. mam.2011.10.006)

Igoillo-Esteve M, Marselli L, Cunha DA, Ladriere L, Ortis F, Grieco FA, Dotta F, Weir GC, Marchetti P, Eizirik DL, et al. 2010 Palmitate induces a pro-inflammatory response in human pancreatic islets that mimics CCL2 expression by beta cells in type 2 diabetes. Diabetologia 53 1395-1405. (doi:10.1007/s00125-010-1707-y)

Inokuchi Y, Nakajima Y, Shimazawa M, Kurita T, Kubo M, Saito A, Sajiki H, Kudo T, Aihara M, Imaizumi K, et al. 2009 Effect of an inducer of $\mathrm{BiP}$, a molecular chaperone, on endoplasmic reticulum (ER) stress-induced retinal cell death. Investigative Ophthalmology \& Visual Science 50 334-344. (doi:10.1167/iovs.08-2123) 
Inoue $\mathrm{H}$, Tanizawa $\mathrm{Y}$, Wasson J, Behn P, Kalidas $\mathrm{K}$, Bernal-Mizrachi E, Mueckler M, Marshall H, Donis-Keller H, Crock P, et al. 1998 A gene encoding a transmembrane protein is mutated in patients with diabetes mellitus and optic atrophy (Wolfram syndrome). Nature Genetics 20 143-148. (doi:10.1038/2441)

Iwasaki Y, Suganami T, Hachiya R, Shirakawa I, Kim-Saijo M, Tanaka M, Hamaguchi M, Takai-Igarashi T, Nakai M, Miyamoto Y, et al. 2014 Activating transcription factor 4 links metabolic stress to interleukin-6 expression in macrophages. Diabetes 63 152-161. (doi:10.2337/db13-0757)

Jonas JC, Bensellam M, Duprez J, Elouil H, Guiot Y \& Pascal SM 2009 Glucose regulation of islet stress responses and beta-cell failure in type 2 diabetes. Diabetes, Obesity and Metabolism 11 (Supplement 4) 65-81. (doi:10.1111/j.1463-1326.2009.01112.x)

Kaneko M, Niinuma Y \& Nomura Y 2003 Activation signal of nuclear factor-kappaB in response to endoplasmic reticulum stress is transduced via IRE1 and tumor necrosis factor receptor-associated factor 2. Biological and Pharmaceutical Bulletin 26 931-935. (doi:10.1248/bpb.26.931)

Kaneto H, Nakatani Y, Kawamori D, Miyatsuka T, Matsuoka TA, Matsuhisa M \& Yamasaki Y 2006 Role of oxidative stress, endoplasmic reticulum stress, and c-Jun N-terminal kinase in pancreatic beta-cell dysfunction and insulin resistance. International Journal of Biochemistry and Cell Biology 38 782-793. (doi:10.1016/j. biocel.2006.01.004)

Kars M, Yang L, Gregor MF, Mohammed BS, Pietka TA, Finck BN, Patterson BW, Horton JD, Mittendorfer B, Hotamisligil GS, et al. 2010 Tauroursodeoxycholic acid may improve liver and muscle but not adipose tissue insulin sensitivity in obese men and women. Diabetes 59 1899-1905. (doi:10.2337/db10-0308)

Kaser A \& Blumberg RS 2010 Endoplasmic reticulum stress and intestinal inflammation. Mucosal Immunology 3 11-16. (doi:10.1038/ mi.2009.122)

Kaser A, Lee AH, Franke A, Glickman JN, Zeissig S, Tilg H, Nieuwenhuis EE, Higgins DE, Schreiber S, Glimcher LH, et al. 2008 XBP1 links ER stress to intestinal inflammation and confers genetic risk for human inflammatory bowel disease. Cell 134 743-756. (doi:10.1016/j.cell.2008.07.021)

Kharroubi I, Ladriere L, Cardozo AK, Dogusan Z, Cnop M \& Eizirik DL 2004 Free fatty acids and cytokines induce pancreatic beta-cell apoptosis by different mechanisms: role of nuclear factor-kappaB and endoplasmic reticulum stress. Endocrinology 145 5087-5096. (doi:10.1210/en.2004-0478)

Kiely A, McClenaghan NH, Flatt PR \& Newsholme P 2007 Proinflammatory cytokines increase glucose, alanine and triacylglycerol utilization but inhibit insulin secretion in a clonal pancreatic betacell line. Journal of Endocrinology 195 113-123. (doi:10.1677/ JOE-07-0306)

Kim MK, Cho JH, Lee JJ, Son MH \& Lee KJ 2015 Proteomic analysis of INS-1 rat insulinoma cells: ER stress effects and the protective role of exenatide, a GLP-1 receptor agonist. PLOS ONE 10 e0120536. (doi:10.1371/journal.pone.0120536)

Kodama K, Nishio Y, Sekine O, Sato Y, Egawa K, Maegawa H \& Kashiwagi A 2005 Bidirectional regulation of monocyte chemoattractant protein-1 gene at distinct sites of its promoter by nitric oxide in vascular smooth muscle cells. American Journal of Physiology: Cell Physiology 289 C582-C590. (doi:10.1152/ ajpcell.00558.2004)

Kudo T, Kanemoto S, Hara H, Morimoto N, Morihara T, Kimura R, Tabira T, Imaizumi K \& Takeda M 2008 A molecular chaperone inducer protects neurons from ER stress. Cell Death and Differentiation 15 364-375. (doi:10.1038/sj.cdd.4402276)

Kwon DY, Kim YS, Ahn IS, Kim da S, Kang S, Hong SM \& Park S 2009 Exendin-4 potentiates insulinotropic action partly via increasing beta-cell proliferation and neogenesis and decreasing apoptosis in association with the attenuation of endoplasmic reticulum stress in islets of diabetic rats. Journal of Pharmacology Science 111 361-371. (doi:10.1254/jphs.09178FP)

Ladriere L, Igoillo-Esteve M, Cunha DA, Brion JP, Bugliani M, Marchetti P, Eizirik DL \& Cnop M 2010 Enhanced signaling downstream of ribonucleic acid-activated protein kinase-like endoplasmic reticulum kinase potentiates lipotoxic endoplasmic reticulum stress in human islets. Journal of Clinical Endocrinology and Metabolism 95 1442-1449. (doi:10.1210/jc.2009-2322)

Lawrence MC, Borenstein-Auerbach N, McGlynn K, Kunnathodi F, Shahbazov R, Syed I, Kanak M, Takita M, Levy MF \& Naziruddin B 2015 NFAT targets signaling molecules to gene promoters in pancreatic beta-cells. Molecular Endocrinology 29 274-288. (doi:10.1210/me.2014-1066)

Laybutt DR, Preston AM, Akerfeldt MC, Kench JG, Busch AK, Biankin AV \& Biden TJ 2007 Endoplasmic reticulum stress contributes to beta cell apoptosis in type 2 diabetes. Diabetologia 50 752-763. (doi:10.1007/s00125-006-0590-z)

Lee YY, Hong SH, Lee YJ, Chung SS, Jung HS, Park SG \& Park KS 2010 Tauroursodeoxycholate (TUDCA), chemical chaperone, enhances function of islets by reducing ER stress. Biochemical and Biophysical Research Communications 397 735-739. (doi:10.1016/j. bbrc.2010.06.022)

Lee JY, Maeng S, Kang SR, Choi HY, Oh TH, Ju BG \& Yune TY 2014 Valproic acid protects motor neuron death by inhibiting oxidative stress and endoplasmic reticulum stress-mediated cytochrome C release after spinal cord injury. Journal of Neurotrauma 31 582-594. (doi:10.1089/neu.2013.3146)

Lenin R, Sankaramoorthy A, Mohan V \& Balasubramanyam M 2015 Altered immunometabolism at the interface of increased endoplasmic reticulum (ER) stress in patients with type 2 diabetes. Journal of Leukocyte Biology 98 615-622. (doi:10.1189/jlb.3A1214609R)

Lerner AG, Upton JP, Praveen PV, Ghosh R, Nakagawa Y, Igbaria A, Shen S, Nguyen V, Backes BJ, Heiman M, et al. 2012 IRE1alpha induces thioredoxin-interacting protein to activate the NLRP3 inflammasome and promote programmed cell death under irremediable ER stress. Cell Metabolism 16 250-264. (doi:10.1016/j. cmet.2012.07.007)

Li R, Wang R, Li H, Sun S, Zou M \& Cheng G 2015 Short-term and longterm effects of dipeptidyl peptidase- 4 inhibitors in type 2 diabetes mellitus patients with renal impairment: a meta-analysis of randomized controlled trials. Diabetes Metabolism Research and Reviews [in press]. (doi:10.1002/dmrr.2731)

Lipson KL, Fonseca SG, Ishigaki S, Nguyen LX, Foss E, Bortell R, Rossini AA \& Urano F 2006 Regulation of insulin biosynthesis in pancreatic beta cells by an endoplasmic reticulum-resident protein kinase IRE1. Cell Metabolism 4 245-254. (doi:10.1016/j. cmet.2006.07.007)

Lipson KL, Ghosh R \& Urano F 2008 The role of IRE1alpha in the degradation of insulin mRNA in pancreatic beta-cells. PLOS ONE 3 e1648. (doi:10.1371/journal.pone.0001648)

Liu M, Sun J, Cui J, Chen W, Guo H, Barbetti F \& Arvan P 2015 INSgene mutations: from genetics and beta cell biology to clinical disease. Molecular Aspects of Medicine 42 3-18. (doi:10.1016/j. mam.2014.12.001)

Lu PD, Harding HP \& Ron D 2004 Translation reinitiation at alternative open reading frames regulates gene expression in an integrated stress response. Journal of Cell Biology 167 27-33. (doi:10.1083/ jcb.200408003)

Madsbad S 2016 Review of head-to-head comparisons of glucagon-like peptide-1 receptor agonists. Diabetes, Obesity and Metabolism 18 317-332. (doi:10.1111/dom.12596)

Malhotra JD \& Kaufman RJ 2007 Endoplasmic reticulum stress and oxidative stress: a vicious cycle or a double-edged sword? Antioxidants \& Redox Signaling 9 2277-2293. (doi:10.1089/ ars.2007.1782) http://jme.endocrinology-journals.org

DOI: 10.1530/JME-15-0306
() 2016 Society for Endocrinology Printed in Great Britain 
Mandrup-Poulsen T, Pickersgill L \& Donath MY 2010 Blockade of interleukin 1 in type 1 diabetes mellitus. Nature Reviews Endocrinology 6 158-166. (doi:10.1038/nrendo.2009.271)

Marchetti P, Bugliani M, Lupi R, Marselli L, Masini M, Boggi U, Filipponi F, Weir GC, Eizirik DL \& Cnop M 2007 The endoplasmic reticulum in pancreatic beta cells of type 2 diabetes patients. Diabetologia 50 2486-2494. (doi:10.1007/s00125-007-0816-8)

Marhfour I, Lopez XM, Lefkaditis D, Salmon I, Allagnat F, Richardson SJ, Morgan NG \& Eizirik DL 2012 Expression of endoplasmic reticulum stress markers in the islets of patients with type 1 diabetes. Diabetologia 55 2417-2420. (doi:10.1007/s00125-012-2604-3)

Maris M, Overbergh L, Gysemans C, Waget A, Cardozo AK, Verdrengh E, Cunha JP, Gotoh T, Cnop M, Eizirik DL, et al. 2012 Deletion of C/EBP homologous protein (Chop) in C57Bl/6 mice dissociates obesity from insulin resistance. Diabetologia 55 1167-1178. (doi:10.1007/s00125-011-2427-7)

Marre ML, James EA \& Piganelli JD 2015 beta cell ER stress and the implications for immunogenicity in type 1 diabetes. Frontiers in Cell and Developmental Biology 3 67. (doi:10.3389/fcell.2015.00067)

Martinon F, Chen X, Lee AH \& Glimcher LH 2010 TLR activation of the transcription factor XBP1 regulates innate immune responses in macrophages. Nature Immunology 11 411-418. (doi:10.1038/ni.1857)

Maurel M, Chevet E, Tavernier J \& Gerlo S 2014 Getting RIDD of RNA: IRE1 in cell fate regulation. Trends in Biochemical Sciences 39 245-254. (doi:10.1016/j.tibs.2014.02.008)

McCullough KD, Martindale JL, Klotz LO, Aw TY \& Holbrook NJ 2001 Gadd153 sensitizes cells to endoplasmic reticulum stress by downregulating Bcl2 and perturbing the cellular redox state. Molecular Cell Biology 21 1249-1259. (doi:10.1128/МСB.21.4.1249-1259.2001)

McGinty JW, Chow IT, Greenbaum C, Odegard J, Kwok WW \& James EA 2014 Recognition of posttranslationally modified GAD65 epitopes in subjects with type 1 diabetes. Diabetes 63 3033-3040. (doi:10.2337/ db13-1952)

McKenzie MD, Jamieson E, Jansen ES, Scott CL, Huang DC, Bouillet P, Allison J, Kay TW, Strasser A \& Thomas HE 2010 Glucose induces pancreatic islet cell apoptosis that requires the BH3-only proteins Bim and Puma and multi-BH domain protein Bax. Diabetes 59 644-652. (doi:10.2337/db09-1151)

Miani M, Colli ML, Ladriere L, Cnop M \& Eizirik DL 2012 Mild endoplasmic reticulum stress augments the proinflammatory effect of IL-1beta in pancreatic rat beta-cells via the IRE1alpha/XBP1s pathway. Endocrinology 153 3017-3028. (doi:10.1210/en.20112090)

Miyazaki Y, Kaikita K, Endo M, Horio E, Miura M, Tsujita K, Hokimoto S, Yamamuro M, Iwawaki T, Gotoh T, et al. 2011 C/EBP homologous protein deficiency attenuates myocardial reperfusion injury by inhibiting myocardial apoptosis and inflammation. Arteriosclerosis, Thrombosis, and Vascular Biology 31 1124-1132. (doi:10.1161/ ATVBAHA.111.224519)

Mozzini C, Garbin U, Stranieri C, Pasini A, Solani E, Tinelli IA Cominacini L \& Fratta Pasini AM 2015 Endoplasmic reticulum stress and Nrf2 repression in circulating cells of type 2 diabetic patients without the recommended glycemic goals. Free Radical Research 49 244-252. (doi:10.3109/10715762.2014.997229)

Namba T, Tanaka K, Ito Y, Ishihara T, Hoshino T, Gotoh T, Endo M, Sato K \& Mizushima T 2009 Positive role of CCAAT/enhancerbinding protein homologous protein, a transcription factor involved in the endoplasmic reticulum stress response in the development of colitis. American Journal of Pathology 174 1786-1798. (doi:10.2353/ ajpath.2009.080864)

Nauck M 2016 Incretin therapies: highlighting common features and differences in the modes of action of glucagon-like peptide- 1 receptor agonists and dipeptidyl peptidase-4 inhibitors. Diabetes, Obesity and Metabolism 18 203-216. (doi:10.1111/dom.12591)

Nikulina MA, Sandhu N, Shamim Z, Andersen NA, Oberson A, Dupraz P, Thorens B, Karlsen AE, Bonny C \& Mandrup-Poulsen T 2003 The
JNK binding domain of islet-brain 1 inhibits IL-1 induced JNK activity and apoptosis but not the transcription of key proapoptotic or protective genes in insulin-secreting cell lines. Cytokine 24 13-24. (doi:10.1016/S1043-4666(03)00242-4)

Noguchi H, Nakai Y, Matsumoto S, Kawaguchi M, Ueda M, Okitsu T, Iwanaga Y, Yonekawa Y, Nagata H, Minami K, et al. 2005 Cell permeable peptide of JNK inhibitor prevents islet apoptosis immediately after isolation and improves islet graft function. American Journal of Transplantation 5 1848-1855. (doi:10.1111/j.1600-6143.2005.00985.x)

Noguchi H, Matsumoto S, Kobayashi N, Hayashi S, Iwanaga Y, Nagata H, Jackson A, Naziruddin B, Okitsu T \& Levy MF 2008 Effect of JNK inhibitor during islet isolation and transplantation. Transplantation Proceedings 40 379-381. (doi:10.1016/j.transproceed.2008.01.055)

Oh YS, Lee YJ, Kang Y, Han J, Lim OK \& Jun HS 2013 Exendin-4 inhibits glucolipotoxic ER stress in pancreatic beta cells via regulation of SREBP1C and C/EBPbeta transcription factors. Journal of Endocrinology 216 343-352. (doi:10.1530/JOE-12-0311)

Ortis F, Naamane N, Flamez D, Ladriere L, Moore F, Cunha DA, Colli ML, Thykjaer T, Thorsen K, Orntoft TF, et al. 2010 Cytokines interleukin-1beta and tumor necrosis factor-alpha regulate different transcriptional and alternative splicing networks in primary betacells. Diabetes 59 358-374. (doi:10.2337/db09-1159)

Ortis F, Miani M, Colli ML, Cunha DA, Gurzov EN, Allagnat F, Chariot A \& Eizirik DL 2012 Differential usage of NF-kappaB activating signals by IL-1beta and TNF-alpha in pancreatic beta cells. FEBS Letters $\mathbf{5 8 6}$ 984-989. (doi:10.1016/j.febslet.2012.02.021)

Oslowski CM \& Urano F 2011a The binary switch that controls the life and death decisions of ER stressed beta cells. Current Opinion in Cell Biology 23 207-215. (doi:10.1016/j.ceb.2010.11.005)

Oslowski CM \& Urano F $2011 b$ Measuring ER stress and the unfolded protein response using mammalian tissue culture system. Methods in Enzymology 490 71-92. (doi:10.1016/B978-0-12385114-7.00004-0)

Oslowski CM, Hara T, O'Sullivan-Murphy B, Kanekura K, Lu S, Hara M, Ishigaki S, Zhu LJ, Hayashi E, Hui ST, et al. 2012 Thioredoxininteracting protein mediates ER stress-induced beta cell death through initiation of the inflammasome. Cell Metabolism $\mathbf{1 6}$ 265-273. (doi:10.1016/j.cmet.2012.07.005)

Oyadomari S \& Mori M 2004 Roles of CHOP/GADD153 in endoplasmic reticulum stress. Cell Death and Differentiation 11 381-389. (doi:10.1038/sj.cdd.4401373)

Oyadomari S, Araki E \& Mori M 2002a Endoplasmic reticulum stressmediated apoptosis in pancreatic beta-cells. Apoptosis 7 335-345. (doi:10.1023/A:1016175429877)

Oyadomari S, Koizumi A, Takeda K, Gotoh T, Akira S, Araki E \& Mori M $2002 b$ Targeted disruption of the Chop gene delays endoplasmic reticulum stress-mediated diabetes. Journal of Clinical Investigation 109 525-532. (doi:10.1172/JCI14550)

Ozcan U, Yilmaz E, Ozcan L, Furuhashi M, Vaillancourt E, Smith RO, Gorgun CZ \& Hotamisligil GS 2006 Chemical chaperones reduce ER stress and restore glucose homeostasis in a mouse model of type 2 diabetes. Science 313 1137-1140. (doi:10.1126/ science.1128294)

Pal D, Dasgupta S, Kundu R, Maitra S, Das G, Mukhopadhyay S, Ray S, Majumdar SS \& Bhattacharya S 2012 Fetuin-A acts as an endogenous ligand of TLR4 to promote lipid-induced insulin resistance. Nature Medicine 18 1279-1285. (doi:10.1038/nm.2851)

Panayi GS \& Corrigall VM 2006 BiP regulates autoimmune inflammation and tissue damage. Autoimmunity Reviews 5 140-142. (doi:10.1016/j. autrev.2005.08.006)

Penas C, Verdu E, Asensio-Pinilla E, Guzman-Lenis MS, HerrandoGrabulosa M, Navarro X \& Casas C 2011 Valproate reduces CHOP levels and preserves oligodendrocytes and axons after spinal cord injury. Neuroscience 178 33-44. (doi:10.1016/j. neuroscience.2011.01.012) 
Pereira SS \& Alvarez-Leite JI 2014 Low-grade inflammation, obesity, and diabetes. Current Obesisty Reports 3 422-431. (doi:10.1007/s13679014-0124-9)

Peters LR \& Raghavan M 2011 Endoplasmic reticulum calcium depletion impacts chaperone secretion, innate immunity, and phagocytic uptake of cells. Journal of Immunology 187 919-931. (doi:10.4049/ jimmunol.1100690)

Pincus D, Chevalier MW, Aragon T, van Anken E, Vidal SE, El-Samad H \& Walter P 2010 BiP binding to the ER-stress sensor Ire1 tunes the homeostatic behavior of the unfolded protein response. PLoS Biology 8 e1000415. (doi:10.1371/journal.pbio.1000415)

Pirot P, Eizirik DL \& Cardozo AK 2006 Interferon-gamma potentiates endoplasmic reticulum stress-induced death by reducing pancreatic beta cell defence mechanisms. Diabetologia 49 1229-1236. (doi:10.1007/s00125-006-0214-7)

Pirot P, Naamane N, Libert F, Magnusson NE, Orntoft TF, Cardozo AK \& Eizirik DL $2007 a$ Global profiling of genes modified by endoplasmic reticulum stress in pancreatic beta cells reveals the early degradation of insulin mRNAs. Diabetologia 50 1006-1014. (doi:10.1007/s00125007-0609-0)

Pirot P, Ortis F, Cnop M, Ma Y, Hendershot LM, Eizirik DL \& Cardozo AK 2007b Transcriptional regulation of the endoplasmic reticulum (ER) stress gene Chop in pancreatic insulin producing cells. Diabetes 56 1069-1077. (doi:10.2337/db06-1253)

Pockley AG, Henderson B \& Multhoff G 2014 Extracellular cell stress proteins as biomarkers of human disease. Biochemical Society Transactions 42 1744-1751. (doi:10.1042/BST20140205)

Polak M, Dechaume A, Cave H, Nimri R, Crosnier H, Sulmont V, de Kerdanet M, Scharfmann R, Lebenthal Y, Froguel P, et al. 2008 Heterozygous missense mutations in the insulin gene are linked to permanent diabetes appearing in the neonatal period or in early infancy: a report from the French ND (Neonatal Diabetes) Study Group. Diabetes 57 1115-1119. (doi:10.2337/db07-1358)

Raghavan M, Wijeyesakere SJ, Peters LR \& Del Cid N 2013 Calreticulin in the immune system: ins and outs. Trends in Immunology 34 13-21. (doi:10.1016/j.it.2012.08.002)

Rao J, Yue S, Fu Y, Zhu J, Wang X, Busuttil RW, Kupiec-Weglinski JW, Lu L \& Zhai Y 2014 ATF6 mediates a pro-inflammatory synergy between ER stress and TLR activation in the pathogenesis of liver ischemia-reperfusion injury. American Journal of Transplantation 14 1552-1561. (doi:10.1111/ajt.12711)

Rasschaert J, Liu D, Kutlu B, Cardozo AK, Kruhoffer M, Orntoft TF \& Eizirik DL 2003 Global profiling of double stranded RNA- and IFNgamma-induced genes in rat pancreatic beta cells. Diabetologia $\mathbf{4 6}$ 1641-1657. (doi:10.1007/s00125-003-1245-y)

Rondas D, Crevecoeur I, D'Hertog W, Ferreira GB, Staes A, Garg AD, Eizirik DL, Agostinis P, Gevaert K, Overbergh L, et al. 2015 Citrullinated glucose-regulated protein 78 is an autoantigen in type 1 diabetes. Diabetes 64 573-586. (doi:10.2337/ db14-0621)

Salvado L, Palomer X, Barroso E \& Vazquez-Carrera M 2015 Targeting endoplasmic reticulum stress in insulin resistance. Trends in Endocrinology and Metabolism 26 438-448. (doi:10.1016/j. tem.2015.05.007)

Santin I, Moore F, Colli ML, Gurzov EN, Marselli L, Marchetti P \& Eizirik DL 2011 PTPN2, a candidate gene for type 1 diabetes, modulates pancreatic beta-cell apoptosis via regulation of the BH3only protein Bim. Diabetes 60 3279-3288. (doi:10.2337/db11-0758)

Satoh T, Abiru N, Kobayashi M, Zhou H, Nakamura K, Kuriya G, Nakamura H, Nagayama Y, Kawasaki E, Yamasaki H, et al. 2011 CHOP deletion does not impact the development of diabetes but suppresses the early production of insulin autoantibody in the NOD mouse. Apoptosis 16 438-448. (doi:10.1007/s10495-011-0576-2)

Scheuner D, Mierde DV, Song B, Flamez D, Creemers JW, Tsukamoto K, Ribick M, Schuit FC \& Kaufman RJ 2005 Control of mRNA translation preserves endoplasmic reticulum function in beta cells and maintains glucose homeostasis. Nature Medicine 11 757-764. (doi:10.1038/nm1259)

Seino Y, Nanjo K, Tajima N, Kadowaki T, Kashiwagi A, Araki E, Ito C, Inagaki $\mathrm{N}$, Iwamoto $\mathrm{Y} \&$ Committee of the Japan Diabetes Society on the Diagnostic Criteria of Diabetes Mellitus 2010 Report of the committee on the classification and diagnostic criteria of diabetes mellitus. Journal of Diabetes Investigation 1 212-228. (doi:10.1111/j.2040-1124.2010.00074.x)

Seo HY, Kim YD, Lee KM, Min AK, Kim MK, Kim HS, Won KC, Park JY, Lee KU, Choi HS, et al. 2008 Endoplasmic reticulum stress-induced activation of activating transcription factor 6 decreases insulin gene expression via up-regulation of orphan nuclear receptor small heterodimer partner. Endocrinology 149 3832-3841. (doi:10.1210/ en.2008-0015)

Shaulian E \& Karin M 2001 AP-1 in cell proliferation and survival. Oncogene 20 2390-2400. (doi:10.1038/sj.onc.1204383)

Shih VF, Tsui R, Caldwell A \& Hoffmann A 2011 A single NFkappaB system for both canonical and non-canonical signaling. Cell Research 21 86-102. (doi:10.1038/cr.2010.161)

Shoda H, Fujio K, Shibuya M, Okamura T, Sumitomo S, Okamoto A, Sawada T \& Yamamoto K 2011 Detection of autoantibodies to citrullinated BiP in rheumatoid arthritis patients and proinflammatory role of citrullinated BiP in collagen-induced arthritis. Arthritis Research and Therapy 13 R191.

Simon-Szabo L, Kokas M, Mandl J, Keri G \& Csala M 2014 Metformin attenuates palmitate-induced endoplasmic reticulum stress, serine phosphorylation of IRS-1 and apoptosis in rat insulinoma cells. PLoS ONE 9 e97868. (doi:10.1371/journal.pone.0097868)

Singh RK, Gupta B, Tripathi K \& Singh SK 2015 Anti oxidant potential of metformin and pioglitazone in type 2 diabetes mellitus: beyond their anti glycemic effect. Diabetes and Metabolic Syndrome 10 102-104. (doi:10.1016/j.dsx.2015.08.016)

Smith JA, Turner MJ, DeLay ML, Klenk EI, Sowders DP \& Colbert RA 2008 Endoplasmic reticulum stress and the unfolded protein response are linked to synergistic IFN-beta induction via X-box binding protein 1. European Journal of Immunology 38 1194-1203. (doi:10.1002/eji.200737882)

Song B, Scheuner D, Ron D, Pennathur S \& Kaufman RJ 2008 Chop deletion reduces oxidative stress, improves beta cell function, and promotes cell survival in multiple mouse models of diabetes. Journal of Clinical Investigation 118 3378-3389. (doi:10.1172/JCI34587)

Srinivasan S, Ohsugi M, Liu Z, Fatrai S, Bernal-Mizrachi E \& Permutt MA 2005 Endoplasmic reticulum stress-induced apoptosis is partly mediated by reduced insulin signaling through phosphatidylinositol 3-kinase/Akt and increased glycogen synthase kinase-3beta in mouse insulinoma cells. Diabetes $\mathbf{5 4}$ 968-975. (doi:10.2337) diabetes.54.4.968)

Stoy J, Edghill EL, Flanagan SE, Ye H, Paz VP, Pluzhnikov A, Below JE, Hayes MG, Cox NJ, Lipkind GM, et al. 2007 Insulin gene mutations as a cause of permanent neonatal diabetes. PNAS 104 15040-15044. (doi:10.1073/pnas.0707291104)

Sun J, Cui J, He Q, Chen Z, Arvan P \& Liu M 2015 Proinsulin misfolding and endoplasmic reticulum stress during the development and progression of diabetes. Molecular Aspects of Medicine 42 105-118. (doi:10.1016/j.mam.2015.01.001)

Suyama K, Ohmuraya M, Hirota M, Ozaki N, Ida S, Endo M, Araki K, Gotoh T, Baba H \& Yamamura K 2008 C/EBP homologous protein is crucial for the acceleration of experimental pancreatitis. Biochemical and Biophysical Research Communications 367 176-182. (doi:10.1016/j.bbrc.2007.12.132)

Szkudelski T \& Szkudelska K 2015 Resveratrol and diabetes: from animal to human studies. Biochimica et Biophysica Acta 1852 1145-1154. (doi:10.1016/j.bbadis.2014.10.013)

Tabas I \& Ron D 2011 Integrating the mechanisms of apoptosis induced by endoplasmic reticulum stress. Nature Cell Biology 13 184-190. (doi:10.1038/ncb0311-184) 
Tam AB, Mercado EL, Hoffmann A \& Niwa M 2012 ER stress activates NF-kappaB by integrating functions of basal IKK activity, IRE1 and PERK. PLOS ONE 7 e45078. (doi:10.1371/journal.pone.0045078)

Tan BM, Zammit NW, Yam AO, Slattery R, Walters SN, Malle E \& Grey ST 2013 Baculoviral inhibitors of apoptosis repeat containing (BIRC) proteins fine-tune TNF-induced nuclear factor kappaB and c-Jun N-terminal kinase signalling in mouse pancreatic beta cells. Diabetologia 56 520-532. (doi:10.1007/s00125-012-2784-X)

Tersey SA, Nishiki Y, Templin AT, Cabrera SM, Stull ND, Colvin SC, Evans-Molina C, Rickus JL, Maier B \& Mirmira RG 2012 Islet betacell endoplasmic reticulum stress precedes the onset of type 1 diabetes in the nonobese diabetic mouse model. Diabetes $\mathbf{6 1}$ 818-827. (doi:10.2337/db11-1293)

Tonnesen MF, Grunnet LG, Friberg J, Cardozo AK, Billestrup N, Eizirik DL, Storling J \& Mandrup-Poulsen T 2009 Inhibition of nuclear factor-kappaB or Bax prevents endoplasmic reticulum stressbut not nitric oxide-mediated apoptosis in INS-1E cells. Endocrinology 150 4094-4103. (doi:10.1210/en.2009-0029)

Tran K, Li Y, Duan H, Arora D, Lim HY \& Wang W 2014 Identification of small molecules that protect pancreatic beta cells against endoplasmic reticulum stress-induced cell death. ACS Chemical Biology 9 2796-2806. (doi:10.1021/cb500740d)

Tsunekawa S, Yamamoto N, Tsukamoto K, Itoh Y, Kaneko Y, Kimura T, Ariyoshi Y, Miura Y, Oiso Y \& Niki I 2007 Protection of pancreatic beta-cells by exendin-4 may involve the reduction of endoplasmic reticulum stress: in vivo and in vitro studies. Journal of Endocrinology 193 65-74. (doi:10.1677/JOE-06-0148)

Urano F, Wang X, Bertolotti A, Zhang Y, Chung P, Harding HP \& Ron D 2000 Coupling of stress in the ER to activation of JNK protein kinases by transmembrane protein kinase IRE1. Science 287 664-666. (doi:10.1126/science.287.5453.664)

van Belle TL, Coppieters KT \& von Herrath MG 2011 Type 1 diabetes: etiology, immunology, and therapeutic strategies. Physiological Reviews 91 79-118. (doi:10.1152/physrev.00003.2010)

Volchuk A \& Ron D 2010 The endoplasmic reticulum stress response in the pancreatic beta-cell. Diabetes, Obesity and Metabolism 12 (Supplement 2) 48-57. (doi:10.1111/j.1463-1326.2010.01271.x)

Vomund AN, Zinselmeyer BH, Hughes J, Calderon B, Valderrama C, Ferris ST, Wan X, Kanekura K, Carrero JA, Urano F, et al. 2015 Beta cells transfer vesicles containing insulin to phagocytes for presentation to T cells. PNAS 112 E5496-E5502. (doi:10.1073/ pnas.1515954112)

Wali JA, Gurzov EN, Fynch S, Elkerbout L, Kay TW, Masters SL \& Thomas HE 2014 Activation of the NLRP3 inflammasome complex is not required for stress-induced death of pancreatic islets. PLOS ONE 9 e113128. (doi:10.1371/journal.pone.0113128)

Walter P \& Ron D 2011 The unfolded protein response: from stress pathway to homeostatic regulation. Science 334 1081-1086. (doi:10.1126/science.1209038)

Wang JF, Bown C \& Young LT 1999 Differential display PCR reveals novel targets for the mood-stabilizing drug valproate including the molecular chaperone GRP78. Molecular Pharmacology 55 521-527.

Widenmaier SB, Ao Z, Kim SJ, Warnock G \& McIntosh CH 2009 Suppression of p38 MAPK and JNK via Akt-mediated inhibition of apoptosis signal-regulating kinase 1 constitutes a core component of the beta-cell pro-survival effects of glucose-dependent insulinotropic polypeptide. Journal of Biological Chemistry 284 30372-30382. (doi:10.1074/jbc.M109.060178)
Xiao C, Giacca A \& Lewis GF 2011 Sodium phenylbutyrate, a drug with known capacity to reduce endoplasmic reticulum stress, partially alleviates lipid-induced insulin resistance and beta-cell dysfunction in humans. Diabetes 60 918-924. (doi:10.2337/ db10-1433)

Yamada T, Ishihara H, Tamura A, Takahashi R, Yamaguchi S, Takei D, Tokita A, Satake C, Tashiro F, Katagiri H, et al. 2006 WFS1-deficiency increases endoplasmic reticulum stress, impairs cell cycle progression and triggers the apoptotic pathway specifically in pancreatic betacells. Human Molecular Genetics 15 1600-1609. (doi:10.1093/hmg/ dd1081)

Yamaguchi K, Takeda K, Kadowaki H, Ueda I, Namba Y, Ouchi Y, Nishitoh H \& Ichijo H 2013 Involvement of ASK1-p38 pathway in the pathogenesis of diabetes triggered by pancreatic ss cell exhaustion. Biochimica et Biophysica Acta 1830 3656-3663. (doi:10.1016/j.bbagen.2013.01.029)

Yamazaki H, Hiramatsu N, Hayakawa K, Tagawa Y, Okamura M, Ogata R, Huang T, Nakajima S, Yao J, Paton AW, et al. 2009 Activation of the Akt-NF-kappaB pathway by subtilase cytotoxin through the ATF6 branch of the unfolded protein response. Journal of Immunology 183 1480-1487. (doi:10.4049/jimmunol.0900017)

Yang C, Diiorio P, Jurczyk A, O'Sullivan-Murphy B, Urano F \& Bortell R 2013 Pathological endoplasmic reticulum stress mediated by the IRE1 pathway contributes to pre-insulitic beta cell apoptosis in a virus-induced rat model of type 1 diabetes. Diabetologia $\mathbf{5 6}$ 2638-2646. (doi:10.1007/s00125-013-3044-4)

Yin J, Peng Y, Wu J, Wang Y \& Yao L 2014 Toll-like receptor 2/4 links to free fatty acid-induced inflammation and beta-cell dysfunction. Journal of Leukocyte Biology 95 47-52. (doi:10.1189/jlb.0313143)

Yoshihara E, Masaki S, Matsuo Y, Chen Z, Tian H \& Yodoi J 2014 Thioredoxin/Txnip: redoxisome, as a redox switch for the pathogenesis of diseases. Frontiers in Immunology 4 514. (doi:10.3389/ fimmu.2013.00514)

Yusta B, Baggio LL, Estall JL, Koehler JA, Holland DP, Li H, Pipeleers D, Ling Z \& Drucker DJ 2006 GLP-1 receptor activation improves beta cell function and survival following induction of endoplasmic reticulum stress. Cell Metabolism 4 391-406. (doi:10.1016/j. cmet.2006.10.001)

Zeng L, Liu YP, Sha H, Chen H, Qi L \& Smith JA 2010 XBP-1 couples endoplasmic reticulum stress to augmented IFN-beta induction via a cis-acting enhancer in macrophages. Journal of Immunology $\mathbf{1 8 5}$ 2324-2330. (doi:10.4049/jimmunol.0903052)

Zhang S \& Kim KH 1995 TNF-alpha inhibits glucose-induced insulin secretion in a pancreatic beta-cell line (INS-1). FEBS Letters 377 237-239. (doi:10.1016/0014-5793(95)01272-9)

Zhang K, Wong HN, Song B, Miller CN, Scheuner D \& Kaufman RJ 2005 The unfolded protein response sensor IRE1alpha is required at 2 distinct steps in B cell lymphopoiesis. Journal of Clinical Investigation 115 268-281. (doi:10.1172/JCI200521848)

Zhang Z, Tong N, Gong Y, Qiu Q, Yin L, Lv X \& Wu X 2011 Valproate protects the retina from endoplasmic reticulum stress-induced apoptosis after ischemia-reperfusion injury. Neuroscience Letters 504 88-92. (doi:10.1016/j.neulet.2011.09.003)

Ziogas A, Muders MH, Economopoulou M, Sprott D, Grossklaus S, Siegert G, Baretton GB, Mitroulis I \& Chavakis T 2015 Endothelialspecific X-box binding protein 1 deficiency limits tumor necrosis factor-induced leukocyte recruitment and vasculitis. Arthritis \& Rheumatology 67 3279-3285. (doi:10.1002/art.39309)

Received in final form 25 March 2016

Accepted 11 April 2016

Accepted Preprint published online 11 April 2016 http://jme.endocrinology-journals.org

DOI: 10.1530/JME-15-0306
() 2016 Society for Endocrinology Printed in Great Britain
Published by Bioscientifica Ltd 